\title{
CAN Mr ZAOUI FREELY CROSS THE FORESHORE AND SEABED? THE EFFECTIVENESS OF UN HUMAN RigHTS MONITORING MECHANISMS IN NEW ZEALAND
}

\author{
Jasper Krommendijk*
}

\begin{abstract}
This article analyses the impact and effectiveness of the most important international monitoring mechanism for New Zealand's international human rights obligations, which is the process of State reporting under United Nations human rights treaties by committees of experts. This article concludes that the organisation of this process in New Zealand has improved since the mid-2000s and that domestic actors, such as the New Zealand Human Rights Commission and nongovernmental organisations, have become more involved. There is, however, no structural follow-up to the recommendations of the supervisory United Nations committees, and as a result they often remain largely ineffective. This article will explain why the reporting process under the United Nations Convention on the Rights of the Child is considerably more effective.
\end{abstract}

Former Minister of Justice, the Hon Simon Power, stated that New Zealand's "record on human rights is among the best in the world". ${ }^{1}$ Likewise, the New Zealand Human Rights Commission

* PhD researcher, Maastricht University. Email: j.krommendijk@maastrichtuniversity.nl. This article is part of a more extensive $\mathrm{PhD}$ research project that is being conducted from November 2009 until March 2014 and that focuses on the impact and effectiveness of State reporting in the Netherlands, New Zealand and Finland. The author was a visiting researcher at Victoria University of Wellington in June 2012. He would like to thank Dr Petra Butler, Dr Bevan Marten, Professor Janet McLean and Peter Shuttleworth for their valuable comments on an earlier version. All errors remain the author's sole responsibility. A separate article will be published about the Convention on the Elimination of all forms of Discrimination Against Women: Jasper Krommendijk "Just 'a little UN Committee' or important policy driver? The impact and effectiveness of the CEDAW Committee in New Zealand" Tijdschrift voor Genderstudies (translation: Journal for Gender Studies) (forthcoming).

1 Hon Simon Power, former Minister of Justice "Speech to Bill of Rights Act Symposium" (Wellington, 11 November 2010). 
(NZHRC) concluded that "New Zealand meets international human rights standards in many respects, and often surpasses them". ${ }^{2}$ International human rights standards are to be found in United Nations (UN) human rights treaties (HRTs). ${ }^{3}$ All State parties are required to submit periodically usually every four or five years - a report on the implementation of each treaty. ${ }^{4}$ This report is examined by an independent committee of experts (a treaty body (TB)), through a so-called constructive dialogue with representatives of the State party. Members of civil society and nongovernmental organisations (NGOs) are allowed to submit alternative information to the TB in shadow reports. The assessment of the State report ends with the adoption of legally non-binding concluding observations (COs), which contain suggestions and recommendations for improved implementation of the treaty standards.

2 This conclusion was reached by the New Zealand Human Rights Commission [NZHRC] in 2004 after an extensive study and consultation about the state of human rights in New Zealand: NZHRC Human Rights in New Zealand Today: Ngā Tika Tangata O Te Motu (September 2004) at ch 21. Not surprisingly, this finding was subsequently endorsed by the Government: Fifth periodic reports of States parties: New Zealand $\mathrm{CCPR} / \mathrm{C} / \mathrm{NZL} / 5(2008)$ at [5].

3 The six main human rights treaties [HRTs] for New Zealand, which are also the focus of this article, are the Convention on the Elimination of All forms of Racial Discrimination 660 UNTS 195 (opened for signature 21 December 1965, entered into force 4 January 1969) [CERD]; the International Covenant on Civil and Political Rights 999 UNTS 171 (opened for signature 16 December 1966, entered into force 23 March 1976) [ICCPR]; the International Covenant on Economic, Social and Cultural Rights 993 UNTS 3 (opened for signature 16 December 1966, entered into force 3 January 1976) [ICESCR]; the Convention on the Elimination of All Forms of Discrimination Against Women 1249 UNTS 13 (opened for signature 18 December 1979, entered into force 3 September 1981) [CEDAW]; the Convention against Torture and Other Cruel, Inhuman or Degrading Treatment or Punishment 1465 UNTS 85 (opened for signature 10 December 1984, entered into force 26 June 1987) [CAT]; and the United Nations Convention on the Rights of the Child 1577 UNTS 3 (opened for signature 20 November 1989, entered into force 2 September 1990) [UNCROC]. The article does not address the Convention on the Rights of Persons with Disabilities 2515 UNTS 3 (opened for signature 30 March 2007, entered into force 3 May 2008) [CRPD], which was ratified only very recently on 26 September 2008. The initial State report of March 2011 has not been considered by the CRPD Committee and there are hence no concluding observations [COs] yet: see First New Zealand Report on Implementing the United Nations Convention on the Rights of Persons with Disabilities CRPD/C/NZL/1 (2011). Due to word limitations this article will not address the universal periodic review [UPR] of the United Nations [UN] Human Rights Council, a peer review mechanism whereby member States scrutinise each others' domestic human rights situations.

4 The ICCPR, ibid, at art 40(1) determines, for example, that:

The States Parties to the present Covenant undertake to submit reports on the measures they have adopted which give effect to the rights recognized herein and on the progress made in the enjoyment of those rights.

For an overview of the reporting status of New Zealand, see Office of the High Commissioner for Human Rights "New Zealand" (2012) United Nations Human Rights <www.ohchr.org〉. Another way in which compliance with some treaties is monitored by these treaty bodies [TBs] is through complaints of individuals. New Zealand accepted this communications procedure under the ICCPR, CERD, CAT and CEDAW. 
On the basis of the opening quotations, one might expect that this process of State reporting and adoption of COs has a considerable influence in New Zealand. This article will seek to unravel whether this assumption holds true. More particularly, this article assesses the effectiveness of the COs, "effectiveness" being understood as the extent to which policy and/or legislative measures have been undertaken as a result of COs. This article will also concentrate on the factors that influence the State when implementing recommendations and taking measures on the basis of the COs. In terms of methodology, the results presented in this article are primarily based on a documentary analysis of parliamentary papers, UN documents and academic literature. In addition, around 60 interviews were held with government officials, former ministers, representatives from NGOs and the NZHRC, academics, lawyers and judges, in June and July 2012.

Part I will outline the impact of the process of State reporting and the COs at the domestic level, and the attention that has been paid by domestic actors - such as Parliament, NGOs, the media and courts - to the COs. Part II touches on the effectiveness of the COs. Part III will discuss several political and cultural factors existing in New Zealand that have contributed to the ineffectiveness of the majority of COs, and will explain why government officials are - with some exceptions - not eager to automatically act upon COs.

\section{DOMESTIC IMPACT AND DOMESTIC MOBILISATION}

\section{A Government}

The Ministry of Foreign Affairs and Trade (MFAT) is responsible for the "overall coordination" of the preparation of State reports. ${ }^{5} \mathrm{Up}$ to 2006, MFAT also compiled the reports for the International Covenant on Civil and Political Rights (ICCPR), the International Covenant on Economic, Social and Cultural Rights (ICESCR), the Convention Against Torture (CAT) and the Convention on the Elimination of all forms of Racial Discrimination (CERD). MFAT often contracted external independent advisors to write the reports. ${ }^{6}$ The Ministry of Women's Affairs (MWA), the Ministry of Youth Affairs (MYA) and the Ministry of Social Development (MSD) were responsible for the reports for the Convention of the Elimination of all forms of Discrimination Against Women (CEDAW) and the United Nations Convention on the Rights of the Child (UNCROC) respectively. ${ }^{7}$ Since 2006, the Bill of Rights and Human Rights Team at the Ministry of

5 Core document forming part of the reports of States parties: New Zealand HRI/CORE/NZL/2010 (2010) at [237].

6 The 2001 State reports under the ICCPR and ICESCR were written by Petra Butler, Associate Professor at Victoria University of Wellington.

7 Responsibility for the compilation of the UNCROC report shifted to the Ministry of Social Development [MSD] during the writing of the combined third and fourth report in 2008. The organisation of the process of reporting is briefly described in New Zealand's Common Core Documents: Core document forming part of the reports of States parties: New Zealand, above n 5, at [237]; and Core document forming the initial part of the reports of States parties: New Zealand HRI/CORE/NZL/2006 (2006) at [132]. 
Justice (MOJ) has become more directly involved in the process of State reporting and has taken over MFAT's responsibility for preparing the reports for the ICCPR, ICESCR, CAT and CERD. ${ }^{8}$

Coincidentally or not, the organisation of the process of reporting has improved since the MOJ has become more involved. This is especially visible in the reduction of delays in the submission of reports to TBs. The State reports that were submitted at the beginning of the millennium (between January and October 2001) saw significant delays: UNCROC (nine months); CERD (21 months); CAT (36 months); ICCPR (72 months); and ICESCR (74 months). The CEDAW report was submitted in October 2002 with a delay of "only" eight months. New Zealand subsequently made a catch-up effort to get completely up-to-date with its reporting obligations. ${ }^{9}$ As a result of this, New Zealand was able to submit its next reports on time (CAT 2007 and UNCROC 2008) or with relatively short delays of a couple of months (CEDAW 2006 and 2010, two and three months respectively; ICCPR 2007, five months; CERD 2006 and 2011, five and two months respectively; and ICESCR 2009, 10 months). The MOJ has also created a comprehensive website comprising information about, and all the documents relating to, the reporting process. ${ }^{10}$

Another improvement is the increased participation of government ministers in the process. ${ }^{11}$ Since 1994, all Associate Ministers for Women's Affairs have headed dialogue with the CEDAW Committee. ${ }^{12}$ More recently, the delegation to the UN Human Rights Committee (UNHRC) in 2010 (and to the Universal Periodic Review in 2009) was headed by the then Minister of Justice, Mr Power. ${ }^{13}$ Almost all government officials interviewed mentioned Mr Power's close personal interest. They noted that the attendance of a minister, and his participation in dialogue, proved the importance of the process.

8 Core document forming the initial part of the reports of States parties: New Zealand, ibid.

9 Summary Record: Fourth periodic report of New Zealand CCPR/C/SR.2015 (2002) at [48].

10 Ministry of Justice [MOJ] "Human Rights" <www.justice.govt.nz>. The Ministry of Foreign Affairs and Trade [MFAT] has a website as well, but this contains hardly any explanation of the process and the documents are also less complete than those on the MOJ website. See MFAT "Human Rights" (24 January 2012) <www.mfat.govt.nz>. MFAT did, however, produce a handbook containing the texts of and information about the treaties: MFAT New Zealand Handbook on International Human Rights (Printlink, Wellington, 2008).

11 NZHRC Human Rights in New Zealand 2010: Ngā Tika Tangata O Aotearoa (December 2010) at 22-23. See also NZHRC Tūi Tūi Tuituiā: Race Relations in 2010 (March 2011) at 6.

12 Hon Katherine O'Regan MP (1994); Deborah Morris MP (1998); Hon Ruth Dyson MP (2003); and Hon Lianne Dalziel MP (2007).

13 The other delegations were headed by the Permanent Representative of New Zealand to the UN Office at Geneva or the Chief Executive of the Ministry of Youth Affairs [MYA] and MSD in the case of UNCROC in 2003 and 2011. 
There has, to date, not been a formal process for considering COs. In particular, for the 2001 and 2002 reports, interviewees observed that there was a post-dialogue feeling that New Zealand had got away "scot-free". In response to an Official Information Act (OIA) request, the MOJ confirmed that "there was no formal consideration of concluding observations between 2003 and 2008" with respect to the ICESCR COs 2003. ${ }^{14}$ This coincides with the problem discussed during the New Zealand Diversity Forum 2009 that COs: ${ }^{15}$

... tend to go on the shelf until just before the next reporting round for a treaty and then there is an urgent message sent out from MFAT to departments asking what have they done to fulfil or implement the recommendations.

It seems, however, that the more recent COs have been taken more seriously, even though a formal process for responding to COs is still absent and remains largely ad hoc and reactionary. Officials provided the Minister of Justice with briefings about the CAT COs 2009 and ICCPR COs 2010, and explained the extent to which new action was required in response to the COs. ${ }^{16}$ This has also happened for CEDAW COs. ${ }^{17}$ A more systematic and continuous approach was in place only for UNCROC COs 1997 and 2003 in the form of an UNCROC Work Programme. ${ }^{18}$ The UNCROC Work Programme was tabled in Cabinet to obtain the agreement of other ministers and to get it into the work programmes of other departments. This was done deliberately because most of the issue areas covered in the COs were the responsibility of other departments.

The COs have only been sporadically referred to by members of Government in Parliament. Ministers have almost never stated during parliamentary debates that a certain policy or legislative

14 Letter from Fiona Illingsworth (Acting Manager of Bill of Rights and Human Rights, MOJ) to Peter Shuttleworth (Committee Member of Action for Children and Youth in Aotearoa Incorporated [ACYA]) regarding the Government's response to and parliamentary scrutiny of COs in the period 2003-2008 (22 May 2012) (Obtained under Official Information Act 1982 Request to the MOJ).

15 Helen P Greatrex "Complementarity: Towards Robust Human Rights Governance in the New Zealand State Sector" (PhD Thesis, Victoria University of Wellington, 2010) at 128-129.

16 Illingsworth, above n 14.

17 The COs 2007 were, for example, discussed by the Ministry of Women's Affairs [MWA] with senior government officials from other departments and the non-governmental organisation [NGO] caucus. The Minister of Women's Affairs sent a letter to other ministers in April 2008 to inform them about the CEDAW COs 2007 and the necessity of reporting on progress in 2010: Seventh periodic report of New Zealand CEDAW/C/NZL/7 (2010) at 75

18 At the time of interviewing (June 2012) there was no work programme for the COs 2011. Instead, officials were thinking about addressing some COs in a future Children's Action Plan proposed in the Green Paper Every child thrives, belongs, achieves (Ministry of Social Development, Green Paper for Vulnerable Children, 2012) which deals with vulnerable children (available online at <www.childrensactionplan.govt.nz>). 
action needed to be taken as a result of the criticisms or recommendations of TBs. ${ }^{19}$ On the contrary, ministers have been remarkably dismissive about the recommendations in public. The most well-known example is the early warning procedure decision of the CERD in relation to the Foreshore and Seabed Act 2004 (FSA) ${ }^{20}$ The day after the CERD Committee made its decision, the Prime Minister stated that: ${ }^{21}$

This is a committee on the outer edges of the UN system. It is not a court. It did not follow any rigorous process as we would understand one. In fact, the process itself would not withstand scrutiny at all.

Well, I think I have a somewhat better understanding of the UN system than they do.

The Hon Dr Michael Cullen, then Deputy Prime Minister, responded to a question by Keith Locke MP (Green Party) about the CAT Committee's 2004 criticism of the security risk certificate procedure applied to Ahmed Zaoui, saying that: ${ }^{22}$

Mr Zaoui is free to cross over the foreshore and seabed at any time, which is more than one can say for some of the countries represented on the United Nations Human Rights Committee at the present stage.

This aggressively defensive reaction was said to be rather surprising and inconsistent with New Zealand's rhetoric on human rights (see Part III B). ${ }^{23}$ Several interviewees noted that the Government's public response to TB findings became more careful, diplomatic and sophisticated in tone after 2006. The Government has adopted a "more low-key approach" by giving less publicity to negative decisions, probably because it has realised that such a strategy is more effective for

19 Only occasionally was this done. Hon Lianne Dalziel MP (Minister of Women's Affairs) quoted the COs 2003 and held that the Human Rights (Women in Armed Forces) Amendment Bill 2007 was "doing precisely what we were asked to do" by the CEDAW Committee: (4 April 2007) 638 NZPD 8678. Hon Phil Goff MP (Minister of Defence) stated something similar: (4 April 2007) 638 NZPD 8684. Hon Christopher Finlayson MP (Attorney-General) mentioned that the UN Human Rights Committee [UNHRC] commended the Immigration Act 2009, in reaction to references by Keith Locke MP (Green Party) and Rahui Katene MP (Māori Party) to the COs 2010: (30 March 2010) 661 NZPD 10104. Likewise, Mr Finlayson referred to the decision of the CERD relating to the Foreshore and Seabed Act 2004 [FSA] in relation to the history leading up to the repeal of this Act: (15 March 2011) 670 NZPD 17181.

20 For a good overview of the decision and the procedure, see Claire Charters and Andrew Erueti "Report From the Inside: the CERD Committee's Review of the Foreshore and Seabed Act 2004" (2005) 36 VUWLR 257.

21 Interview with the Rt Hon Helen Clark, Prime Minister (John Dunne, Breakfast Show TRN 3ZB, 14 March 2005) transcript cited in Charters and Erueti, ibid, at 258 and 286.

22 (9 November 2004) 621 NZPD 16708.

23 Charters and Erueti, above n 20, at 287. 
silencing opposition, and that "complaining about Geneva's intrusion" only added fuel to the flames and further politicised that intrusion. ${ }^{24}$

COs - but also HRTs in general - have played almost no role in legislative policy-making, a point which was also acknowledged by government officials. Formally speaking, all Cabinet papers need to be assessed in light of "international obligations". This requirement was said by those interviewed to be primarily a "tick of the box" exercise or afterthought that does not involve any true consideration of possible human rights implications. This limited scrutiny was attributed to limited expertise, especially in policy departments (other than the Crown Law Office, MOJ and MFAT) that are not particularly familiar with international obligations. Government officials and ministers also noted that references to HRTs in Cabinet papers and policy documents are rare and that HRTs are rarely used as a way of guiding policies.

The COs and HRTs also play a minor part in the s 7 procedure under the New Zealand Bill of Rights Act 1990 (NZBORA), which requires the Attorney-General to report to Parliament where a Bill appears to be inconsistent with the NZBORA. Although the consistency of Bills with HRTs is not examined as such, HRTs can be used in the interpretation of the NZBORA. Particularly for ICCPR reporting, there is a logical rationale for examining this consistency because of the reference to the ICCPR in the Preamble of the NZBORA. A scan of the s 7 reports on the MOJ website shows that the ICCPR has indeed been invoked occasionally. ${ }^{25}$ Of the 58 reports (of which 28 relate to government Bills and 30 to private members' Bills), nine referred to the UNHRC and the ICCPR and another three discussed only the ICCPR. Two out of these nine references concerned the COs for New Zealand. ${ }^{26}$ Of the other HRTs, CAT and UNCROC were mentioned only once. ${ }^{27}$

24 Statements were made in relation to Australia, whose officials had initially reacted forcefully to negative views of TBs as well. See Hilary Charlesworth and others No Country is an Island: Australia and International Law (University of New South Wales Press, Sydney, 2006) at 88.

25 MOJ "Section 7 Reports" <www.justice.govt.nz>.

26 ICCPR COs 1995 were mentioned in relation to the review of sentences in Hon Margaret Wilson Report of the Attorney-General under the New Zealand Bill of Rights Act 1990 on the Criminal Justice (Parole Offenders) Amendment Bill (Office of the Attorney-General, 2000) at [21]. The General Comments [GCs] and the views in individual communications were also both referred to three times. The COs for Belgium were referred to once in relation to the Local Electoral Amendment Bill (No 2) 2001 as an example of the criticism of the UNHRC on restrictions on the publication of opinion polls.

27 CAT COs 2009 were quoted once in relation to the impact of the Prisoners' and Victims' Claims Act 2005 and the right to an effective remedy. ICCPR COs 2010 were also briefly mentioned. In his Report of the Attorney-General under the New Zealand Bill of Rights Act 1990 on the Prisoners' and Victims' Claims (Redirecting Prisoner Compensation) Amendment Bill (Office of the Attorney-General, 13 October 2011) Hon Christopher Finlayson MP stated at [20]-[21] that the proposed Bill "could attract further negative attention". Both the UNCROC and CRPD were mentioned once in Hon Margaret Wilson Report of the Attorney-General under the New Zealand Bill of Rights Act 1990 on the Care of Children Bill (Office of the Attorney-General, 11 June 2003) at [19] and Hon Christopher Finlayson Report of the Attorney-General 
Interestingly, the Supreme Court of Canada (SCC) was referred to almost three times as much as the UNHRC, while the number of references to the European Court of Human Rights (ECTHR) and United Kingdom courts is at least roughly equal. ${ }^{28}$ One explanation for the smaller impact of the ICCPR and the prominence of Canadian jurisprudence is that NZBORA was very much influenced by the Canadian Charter of Rights and Freedoms 1982. In contrast, the New Zealand Government held that the provisions in the ICCPR do "not raise any additional considerations other than those discussed in respect of the BORA rights". ${ }^{29}$ This perspective is confirmed by Bills vetted by the MOJ or sometimes the Crown Law Office that were deemed to be consistent with NZBORA. ${ }^{30}$

These results corroborate with a 2001 re-evaluation study that pointed to the focus of the MOJ on familiarity with the ICCPR, instead of a broader range of international human rights law. ${ }^{31}$ The

under the New Zealand Bill of Rights Act 1990 on the Eden Park Trust Amendment Bill (Office of the Attorney-General, 8 April 2009) at [25] respectively.

2826 references to the Supreme Court of Canada [SCC] were counted, nine to the European Court of Human Rights [ECTHR] (two for the European Convention on Human Rights [ECHR] only) and eight to United Kingdom courts, including the House of Lords. Note, however, that there was no systematic database search option, which explains the mentioning of "at least". The actual number could be higher. Other courts referred to more than once were, amongst others, the Supreme Court of the United States, the Court of Appeal of Ontario, the Constitutional Court of South Africa and courts in Australia and Hong Kong.

29 Fourth periodic report of New Zealand (continued) CCPR/C/SR.2016 (2002) at [33].

30 The UNHRC was addressed in 32 instances and the ICCPR in 37. The SCC (107 times) and the ECTHR (64 times) were referred to more often. CEDAW, the ICESCR and their respective Committees have not been addressed at all in this vetting process. Both the CERD and CAT Committees were referred to once, while the UNCROC Committee was mentioned twice and the UNCROC 12 times. The Report on the Crimes (Reasonable Parental Control and Correction) Amendment Bill (Office of Legal Counsel for the AttorneyGeneral, 2 October 2009) at [9] quoted the UNCROC COs 2003 and referred to the endorsement of these in CAT COs 2004. GC 10 of the UNCROC Committee was mentioned in the context of the Report on the Children Young Persons and their Families (Youth Courts Jurisdiction \& Orders) Amendment Bill (Office of Crown Counsel for the Attorney-General, 5 February 2009) at [5]. The early warning procedure decision of the CERD in relation to the FSA 2004 was cited in the footnotes to the Report on the Marine and Coastal Area (Takutai Moana) Bill (Office of the Acting Attorney-General, 2 September 2010) at $\mathrm{n} 14$. Note that the latter was not found with the search terms in the previous footnote. On 18 July 2012, a search was performed on MOJ "New Zealand Bill of Rights Act 1990" <www.justice.govt.nz/policy> (with the option "only in current section" ticked) with the following terms: "Covenant on Economic, Social and Cultural Rights" (zero results); "Committee on Economic, Social and Cultural Rights" (zero results); "Convention on the Elimination of All Forms of Discrimination Against Women" (zero results); "Committee on the Elimination of All Forms of Discrimination Against Women" (zero results); "Convention Against Torture" (three results); "Committee Against Torture" (one result); "Convention on the Elimination of All Forms of Racial Discrimination" (one result); "Committee on the Elimination of All Forms of Racial Discrimination" (zero results); "Convention on the Rights of the Child" (12 results); "Committee on the Rights of the Child" (two results); "Covenant on Civil and Political Rights" (37 results); and "Human Rights Committee" (32 results).

31 Peter Cooper and others Re-evaluation of The Human Rights Protections in New Zealand (MOJ, October 2000) at [230]. 
study further held that international human rights obligations are generally only taken into account in the government policy-making process at a relatively late stage. ${ }^{32}$ When they are considered at an early stage, which seldom happens, the practice is "patchy, uneven and unsystematic" and dependent upon a particular government official or minister. ${ }^{33}$ The process operates primarily in a negative way, whereby it is considered whether the Bill does not contravene international obligations. The principal objective is to reduce the chance of legal proceedings being brought. In addition, human rights issues are only considered rather superficially. ${ }^{34}$ This is what Claudia Geiringer and Matthew Palmer termed a "checklist" approach to human rights protection. ${ }^{35}$

\section{B Parliament}

Parliament is not involved in the process of reporting by the government. State reports and COs are not sent to or tabled in Parliament. ${ }^{36}$ The government considers the periodic reports to be government reports, which do not require the approval of the House of Representatives. ${ }^{37}$ Despite this, COs have been referred to and discussed in Parliament on a number of occasions. Individual Members of Parliament (MPs) have occasionally picked up on and referred to COs, particularly when they were already campaigning for a certain issue, such as the repeal of the FSA.

32 Cooper and others, ibid, at [28].

33 Cooper and others, above n 31, at [209].

34 Cooper and others, above n 31, at [214].

35 Claudia Geiringer and Matthew SR Palmer "Human Rights and Social Policy in New Zealand" (2007) 30 Social Policy Journal of New Zealand 12 at 33.

36 Illingsworth, above n 14 .

37 Sixth periodic report of New Zealand CEDAW/C/SR.805 (B) (2007) at [48]. 
Table 1: Impact of HRTs and COs in Parliament (2000-2012) $)^{38}$

\begin{tabular}{|l|c|c|c|}
\hline $\begin{array}{c}\text { Number of references in } \\
\text { Parliament to: }\end{array}$ & The HRT or TB & $\begin{array}{c}\text { The process of State } \\
\text { reporting }\end{array}$ & The COs \\
\hline CAT & 23 & 1 & 13 \\
\hline CERD & 6 & - & - \\
\hline ICESCR & 6 & 4 & 6 \\
\hline UNCROC & 72 & 6 & 5 \\
\hline CEDAW & 7 & 1 & 2 \\
\hline ICCPR & 50 & 4 & 9 \\
\hline
\end{tabular}

Table 1 shows that the highest number of references to COs in Parliament related to the CERD, with 13 in total. There were even 18 occasions during which the 2005 early warning procedure decision of the CERD Committee in relation to the FSA was referred to. ${ }^{39}$ Almost all of these references were made by MPs from the Māori Party. This is not surprising, since the political party was founded in 2004 as a result of the FSA saga. Noteworthy is that the Māori Party was also directly involved in the process of State reporting by way of submitting an alternative report to the CERD Committee in May 2007. ${ }^{40}$ In addition to the Māori Party, another political party that has

38 On 14 June 2012, an advanced search was conducted on New Zealand Parliament "Hansard and Journals" <www.parliament.nz>, which contains the transcript of debates in the House of Representatives as well as written and oral questions from all debates since 1 January 2000. The results were: "Committee on Economic, Social and Cultural Rights" (four results); "Covenant on Economic, Social and Cultural Rights" (six results); "Committee Against Torture" (51 results); "Convention Against Torture" (107 results); "Committee on the Elimination of All Forms of Discrimination Against Women" (three results); "Convention on the Elimination of All Forms of Discrimination Against Women" (67 results); "Committee on the Elimination of Racial Discrimination" (82 results); "Convention on the Elimination of All Forms of Racial Discrimination" (28 results); "Committee on the Rights of the Child" (21 results); "Convention on the Rights of the Child" (273 results); "Human Rights Committee" (69 results); and "International Covenant on Civil and Political Rights" (121 results). Note that the table refers to the number of occasions or debates during which the UN HRTs were referred to. This explains why the actual numbers in the table are lower than the search results, which count every reference individually.

39 Six out of these 18 references were made prior to the Committee on the Elimination of Racial Discrimination Decision on Foreshore and Seabed Act 2004 CERD/C/DEC/NZL/1 (2005), and were more procedure related. Reference was primarily made by Māori Party MPs, as well as Metiria Turei MP (Green Party) three times; Sue Kedgley MP (Green Party) three times; and Russell Fairbrother MP (Labour Party) once. During a debate about the FSA, Metiria Turei MP, Nandor Tanczos MP and Keith Locke MP (all Green Party) also referred to the complaint to the CERD Committee.

40 Māori Party Report to the United Nations Committee on the Elimination of Racial Discrimination (Shadow Report, May 2007). 
frequently alluded to COs and HRTs is the Green Party. ${ }^{41}$ The most prominent example is Sue Bradford MP's private members' Bill ${ }^{42}$ which was announced on 6 October 2003 in response to the UNCROC COs 2003 that had been adopted three days earlier. Ms Bradford stated that she was "stirred into political action by the recommendations that the UN Committee on the Rights of the Child made on two occasions". ${ }^{43}$ Reference to HRTs and COs can give small opposition parties in particular some authority and an additional lever in the debate. Such parties use them as a political tool to portray their party as "rights friendly". ${ }^{44}$

What is remarkable is the relatively high number of references to CAT COs. Several factors might have contributed to this. First, the parliamentary discussion of the Crimes of Torture Amendment Act 2006 in the context of the ratification of the Optional Protocol to the Convention Against Torture (OPCAT) ${ }^{45}$ offered an opportunity for MPs to allude to the most recent CAT COs. During all three readings of the Crimes of Torture Amendment Act, the CAT COs 2004 were addressed by Pita Sharples MP and Te Ururoa Flavell MP (Māori Party) and Mr Locke (Green Party). ${ }^{46}$ Second, following OPCAT's ratification, annual reports of the NZHRC about the

41 In a study conducted by Petra Butler about the references to the New Zealand Bill of Rights Act [NZBORA], she pointed to the following quite active MPs - Nandor Tanczos MP, Sue Bradford MP, Keith Locke MP (all Green Party) and Hon Wayne Mapp MP (National Party): Petra Butler "It Takes Two to Tango - Have They Learned Their Steps?" (2011) <http://papers.ssrn.com> at 45.

42 Crimes (Abolition of Force as a Justification for Child Discipline) Amendment Bill 2005 (271-1).

43 Beth Wood, Ian Hassall and George Hook Unreasonable Force: New Zealand's journey towards banning the physical punishment of children (Save the Children New Zealand, Wellington, 2008) at 176 and 204.

44 Petra Butler "It Takes Two to Tango - Have They Learned Their Steps?" above n 41, at 51; Andrew Geddis "Prisoner Voting and Rights Deliberation: How New Zealand's Parliament Failed" [2011] NZ L Rev 443 at 471 .

45 Optional Protocol to the Convention Against Torture and Other Cruel, Inhuman or Degrading Treatment or Punishment 2375 UNTS 237 (opened for signature 4 February 2003, entered into force 22 June 2006) [OPCAT].

46 (21 November 2006) 635 NZPD 6685; (6 November 2006) 635 NZPD 6272 and 6274; (28 March 2006) 630 NZPD 2214 respectively. OPCAT established the Subcommittee Against Torture, which has the mandate to visit places of detention. In addition, OPCAT obliged State parties to appoint a national preventive mechanism [NPM] to carry out visits to places of detention, to monitor the treatment of and conditions for detainees and to make recommendations regarding the prevention of ill treatment. In New Zealand the central NPM is the NZHRC. The Office of the Ombudsman is the NPM for prisons, immigration detention facilities, and health and disability places of detention. The functions of the NPM for child and youth residences are performed by the Ombudsman together with the Office of the Children's Commissioner [OCC]. The Independent Police Conduct Authority is the NPM for people in the custody of the police. The Inspector of Service Penal Establishments is the NPM for New Zealand Defence Force detention facilities. See NZHRC Monitoring Places of Detention: Annual report of activities under the Optional Protocol to the Convention against Torture (OPCAT) 1 July 2010 to 30 June 2011 (February 2012). 
monitoring of places of detention have been tabled in Parliament, providing another chance to discuss or refer to the CAT COs (see Part I D).

Noteworthy is that quite a number of MPs referred to the criticisms or recommendations of the TBs with disapproval and criticised the TBs. These negative reactions primarily came from MPs of the ACT, NZ First and, to a lesser extent, National Parties. Sometimes Labour MPs were also critical of the TBs and their COs or decisions, especially when they related to policy and legislation championed by the Labour Government (1999-2008). ${ }^{47}$ Darren Hughes MP (Labour Party) noted, for example, that: ${ }^{48}$

... people at the fringes of politics have become very excited about a report from a United Nations committee regarding the Foreshore and Seabed Act. But I think it is very important to put on the record that that overseas committee considered that important matter for simply 35 minutes, and that it was not a committee made up of countries that we could say have a better race relations record than New Zealand does.

John Hayes MP (National Party) stated that the "treaty committee system ... is expensive and it is not delivering an iota of value to the people whom I represent in the Wairarapa." 49 Tony Ryall MP (National Party) argued in similar fashion that: "New Zealand has made it quite clear to all the international agencies that we will not follow their rules as we have our own rules." ${ }^{50}$ Future Minister of Justice Mr Power (National Party) was also critical about MPs who would like to have the recommendations of the UNHRC implemented "lickety-split". ${ }^{51}$ Stephen Franks MP (ACT Party) went even further by stating that: ${ }^{52}$

... this Government now claims, absolutely falsely, that we are obliged by the United Nations Human Rights Committee, the members of which are appointed by some of the most disgusting, vile, and cruel dictators on this earth. Mr Mugabe has a nominee on the United Nations Human Rights Committee, as

47 See for example some critical, albeit nuanced, remarks of Russell Fairbrother MP (Labour Party) in relation to the FSA: (23 November 2005) 628 NZPD 422. More unconditional support for the TBs and their criticism comes from the Green Party and the Māori and Mana Parties.

48 (16 March 2005) 624 NZPD 19241.

49 (21 November 2006) 630 NZPD 2218. During the first and second reading of the Bill, Mr Hayes expressed similar criticism as to the bureaucratic nature of the 10-year negotiation process of OPCAT: (28 March 2006) 630 NZPD 2218. He also noted that New Zealand has a leadership role in relation to human rights and it is already complying with the obligations under OPCAT: (7 November 2006) 635 NZPD 6270.

50 (12 May 2005) 625 NZPD 20555.

51 (14 October 2003) 612 NZPD 9158.

52 (1 June 2005) 626 NZPD 20970 and 21023. On an earlier occasion Mr Franks stated: "The international bureaucrats, and the torturers, the robbers, and the tyrants who put people on to the United Nations Human Rights Committee, have said that New Zealand cannot do it": (12 May 2005) 625 NZPD 20564. 
does the Sudan - a country that is arresting people who are reporting mass rape - and this Government

says we kowtow, in this country, to the United Nations Human Rights Committee!

This quote also illustrates that MPs often confuse the UNHRC with the Human Rights Council, or the former Commission.

These findings coincide with the conclusions of several scholars that Parliament has hardly discussed or paid attention to the NZBORA or human rights. The focus of these authors has been on the extent to which Parliament has considered s 7 reports or has been willing to adopt a Bill without addressing NZBORA inconsistencies. Their research suggests that MPs have rarely used the Attorney-General's s 7 reports to question or discuss government Bills in a comprehensive way. ${ }^{53}$ In addition, Parliament continued to adopt legislation, even where the Attorney-General expressed doubts about its conformity with NZBORA. ${ }^{54}$ One could argue that if Parliament easily overlooks NZBORA issues, they are even more likely to ignore HRTs or COs altogether. In addition, if Parliament can or does ignore s 7 reports and legislates against NZBORA, it is to be expected that they feel even less constrained from doing so by HRTs or COs, as the quotations above show.

Several explanations can be given for the limited parliamentary attention paid to HRTs in general and COs in particular. First of all, interviewees noted that MPs' awareness and knowledge of

53 Janet McLean noted that the enactment of NZBORA has not attracted more anxious scrutiny of Bills and in many respects the moral tone of the debates has declined: Janet McLean "The New Zealand Bill of Rights Act 1990 and Constitutional Propriety" (unpublished paper, 2011) (forthcoming). Janet Hiebert also referred to the "misplaced confidence" that parliamentary Bills of Rights increase the ability of parliaments to scrutinise legislation: Janet L Hiebert "Governing Like Judges?" in Tom Campbell, KD Ewing and Adam Tomkins (eds) The Legal Protection of Human Rights: Sceptical Essays (Oxford University Press, Oxford, 2011) 40 at 60. James Kelly even stated that political rights reviews and Parliament itself "has been reduced to theatre - a prepared script performed by actors with clear outcomes and directions from the front benches." NZBORA has, in his view, functioned as an "under-insured" Bill of Rights. See James B Kelly "Judicial and Political Review as Limited Insurance: the Functioning of the New Zealand Bill of Rights Act in 'Hard' Cases" (2011) 49 Commonwealth and Comparative Politics 295 at 308. See also Tessa Bromwich "Parliamentary rights-vetting under the NZBORA" [2009] NZLJ 189; Janet L Hiebert "Rights-vetting in New Zealand and Canada: Similar Idea, Different Outcomes" (2005) 3 NZJPIL 36 at 88; and Geddis "Prisoner Voting and Rights Deliberation: How New Zealand's Parliament Failed", above n 44. For slightly more positive views, see Paul Rishworth "The Bill of Rights and Rights Dialogue in New Zealand: After 20 years, What Counts as Success?" (Paper presented to University of Sydney Workshop on Judicial Supremacy or Inter-Institutional Dialogue: Political Responses to Judicial Review, Sydney Law School, Sydney, May 2010) as cited in McLean "The New Zealand Bill of Rights Act 1990 and Constitutional Propriety" (unpublished paper, 2011) at 21 (forthcoming); and Petra Butler "It Takes Two to Tango - Have They Learned Their Steps?", above n 41, at 51.

54 Kelly, ibid, at 308-309. Paul Rishworth held that a s 7 report in relation to these law and order issues has become a "badge of honour": Rishworth as cited in McLean, ibid, at 22. See also Claire Charters "Responding to Waldron's Defence of Legislatures: Why New Zealand's Parliament Does Not Protect Rights in Hard Cases" [2006] NZ L Rev 621; Andrew Geddis "The Comparative Irrelevance of the NZBORA to Legislative Practice" (2009) 23 NZULR 465 at 477-479. 
UN processes is fairly limited and, thus, depends very much upon individual MPs' knowledge. Second, because there is no freestanding Parliamentary Committee on Human Rights as there is in the United Kingdom, there is no inbuilt interest in and commitment to international human rights obligations. Third, it is difficult for MPs to use COs or HRTs or to put something on the agenda when it is not reported on in the media (see Part I F). Fourth, and most important, is the absence of information coming from the Government. One interviewed MP stated that if NGOs had not been involved in the process or been to Geneva, no information would get through to New Zealand. Reference to COs or HRTs was often the result of work by NGOs or interested individuals and lawyers who alerted MPs to the COs. A recent example of this occurring is Jan Logie MP's (Green Party) media release in which she highlighted the ICESCR Committee's criticism of welfare reforms. ${ }^{55}$ This was brought to her attention by the NGO Peace Movement Aotearoa (PMA). ${ }^{56}$ Likewise, Tariana Turia MP (Māori Party) referred to the fact that barrister Tony Ellis drew attention to the CAT COs 2004 in relation to compensation of prisoners ${ }^{57}$ During the same debate, David Clendon MP (Green Party) referred to a Law Society report that also addressed the COs. ${ }^{58}$ As Part I E shows, NGO advocacy has, however, not been structured enough to keep Parliament fully up-to-date.

\section{National Courts and Legal Practice}

Although international human rights law has increasingly been used ${ }^{59}$ and relied on by courts in various ways,${ }^{60} \mathrm{COs}$ have hardly had any impact, if at all. The only case known to the author is that

55 Green Party "UN advises Govt it's not too late to cancel welfare reforms" (press release, 22 May 2012). See also, for example, Radio New Zealand "The United Nations has criticised New Zealand's proposed welfare reforms for breaching human rights" Radio New Zealand News (22 May 2012) <www.radionz.co.nz> .

56 Email from Jan Logie (Green Party MP) to the author replying to a question from the author regarding how the criticism had come to her attention (14 June 2012).

57 (22 June 2010) 664 NZPD 12065.

58 (22 June 2010) 664 NZPD 12087.

59 John W Hopkins talked about "a modified monism ... [of a] judge-made nature": John W Hopkins "New Zealand" in Dinah Shelton (ed) International Law and Domestic Legal Systems: Incorporation, Transformation, and Persuasion (Oxford University Press, Oxford, 2011) 429 at 446-447. Claudia Geiringer also pointed to the move from distrust to considerable receptivity to international law, which she labelled as a quiet revolution: Claudia Geiringer "International Law through the Lens of Zaoui: Where is New Zealand At?" (2006) 17 Public Law Review 300 at 300 and 309.

60 This Part will not discuss the ways in which courts have used international law as a rhetorical device or justification for the court's own interpretation or with the two models of mandatory considerations for the executive and the presumption of consistency. For a good overview, see Hopkins in Shelton, ibid; Geiringer "International Law through the Lens of Zaoui: Where is New Zealand At?", ibid; Claudia Geiringer "Tavita and All That: Confronting the Confusion Surrounding Unincorporated Treaties and Administrative Law" (2004) 21 NZULR 66; and Claudia Geiringer "The Principle of Legality and the Bill of Rights Act: A Critical Examination of $R v$ Hansen" (2008) 6 NZPJIL 59. For an earlier study about the ways in which 
of the CAT Committee COs 2004 that were invoked before the Supreme Court by barrister Tony Ellis in Taunoa $v$ Attorney-General, albeit with no result. ${ }^{61}$

A study undertaken by Mark Gobbi found that the two HRTs that have been addressed most often by the courts between 20 December 1999 and 30 June 2010 were UNCROC ${ }^{62}$ and the ICCPR, 163 and 164 times respectively. ${ }^{63}$ Only sporadically do courts refer to other HRTs. ${ }^{64}$ Other studies have looked at the number of times TB output has been cited in particular. A study conducted by James Allan, Grant Huscroft and Nessa Lynch in 2007 found 17 cases in which the UNHRC was cited. Interestingly, this study found that the ECTHR judgments, as well as those of Canadian and American jurisdictions, have been cited more often than the UNHRC. ${ }^{65}$ The UNCROC and ICESCR Committees were both cited once. Earlier, in 1999, Butler and Butler concluded that the number of references to the UNHRC is still minimal. ${ }^{66}$ In 1999 , there were only five cases in which the views of the UNHRC were referred to. ${ }^{67}$ The authors also noted that the number of references to

courts can deal with unincorporated treaties, see Law Commission A New Zealand Guide to International Law and its Sources (NZLC R34, 1996).

61 Note that Elias CJ referred to the CAT Committee as the Committee for the Prevention of Torture, mixing it up with the European Convention for the Prevention of Torture and Inhuman or Degrading Treatment or Punishment CETS 126 (opened for signature 26 November 1987, entered into force 1 February 1989). The Chief Justice referred to the recommendation to conduct an inquiry leading to the decision of the High Court in Taunoa v Attorney-General. However, the Supreme Court, and especially the Chief Justice, discussed extensively GC 20 and the views of the UNHRC in individual communications as well as the ICCPR State report 2001: see Taunoa v Attorney-General [2007] NZSC 70, [2008] 1 NZLR 429 at [31], [59], [77]-[78], [80]-[82], [84]-[85], [91], [93], [102] and [104] per Elias CJ; [163]-[169], [187] and [228] per Blanchard J; and [355] and [360] per McGrath J.

62 One explanation for the prominent role of UNCROC in legal practice is the Tavita case of 1994, which rather extensively discussed UNCROC as well as the ICCPR and the case law of the ECTHR. The Court of Appeal held UNCROC to be a mandatory consideration for State officials when they exercise discretion in matters affecting children: Tavita $v$ Minister of Immigration [1994] 2 NZLR 257 (CA).

63 Mark Gobbi "Treaty Action and Implementation" (2004) 1 NZYIL 223; (2005) 2 NZYIL 357; (2006) 3 NZYIL 221; (2007) 4 NZYIL 311; (2007-2008) 5 NZYIL 279; (2008) 6 NZYIL 379; (2010) 7 NZYIL 381.

64 CAT (nine times); ICESCR (eight times); CEDAW (once); and CERD (zero times). Up to 2004, there were only five claims made under art 3 of CAT: Third periodic report of New Zealand (continued) CAT/C/SR.607 (2004) at [3].

65 James Allan, Grant Huscroft and Nessa Lynch "The Citation of Overseas Authority in Rights Litigation in New Zealand: How Much Bark? How Much Bite?" (2007) 11 Otago L Rev 433 at 438.

66 Andrew Butler and Petra Butler "The Judicial Use of International Human Rights Law in New Zealand" (1999) 29 VUWLR 173 at 184, ns 51-52; Andrew Butler and Petra Butler The New Zealand Bill of Rights Act: A Commentary (LexisNexis NZ, Wellington, 2005) at [4.5.2].

67 Two of these also mentioned the GCs of the UNHRC. These five cases are: $R v$ Goodwin (No 2) [1993] 2 NZLR 390 (CA); Simpson v Attorney-General [1994] NZLR 667 (CA); Martin v District Court at Tauranga [1995] 1 NZLR 491 (HC) [Martin]; $R$ v B (1994) 12 CRNZ 681 (HC); Quilter v Attorney-General [1998] 1 NZLR 523 (CA) [Quilter]. Martin and Quilter also mentioned the UNHRC's GCs. The 2009 
European Convention on Human Rights (ECHR) jurisprudence was four times higher than the UNHRC. ${ }^{68}$

The impact of the ICCPR and the views of the UNHRC are rather minor in light of the total number of cases in which NZBORA rights or human rights are potentially at stake. According to the Government, there were over 2,500 decisions that referred to NZBORA between 2000 and 2009, while there were 156 judgments of the superior courts that mentioned the ICCPR. ${ }^{69}$ Butler and Butler counted 35 judgments in 2005 referring to the ICCPR out of a total of more than 200 judgments reported, and noted that the ICCPR's impact has been primarily rhetorical instead of interpretive. ${ }^{70}$ Andrew Geddis argued that the absence of a binding enforcement mechanism under the ICCPR weakens courts' leeway to engage in an all too bold teleological interpretation. ${ }^{71}$ As was stated above, the ECTHR has been cited more often. ${ }^{72}$ In Butler and Butlers' view, the reason for this is unfamiliarity with and limited access to the work and output of the UNHRC. ${ }^{73}$ James Allan,

Government replies to the Letter of Intent mentioned another five cases in which GCs and views of the UNHRC were referred to: Taunoa v Attorney-General, above n 61; Hansen v R [2007] NZSC 7, [2007] 3 NZLR 1; Hosking v Runting [2005] 1 NZLR 1 (CA); Attorney-General v Zaoui [2005] NZSC 38, [2006] 1 NZLR 289; and Mist v R [2005] NZSC 77, [2006] 3 NZLR 145. See Replies to the List of Issues to be Taken Up in Connection with the Consideration of the Fifth Periodic Report of New Zealand CCPR/C/NZL/Q/5/Add.1 (2010) at 11. In the recent case of Atkinson, the Court of Appeal noted that the approach of the respondents and NZHRC as intervener was consistent with the approach of the UNHRC in GC 18. It also reproduced art 26 of the ICCPR, art 2(2) of the ICESCR and art 23(5) of the CRPD: Ministry of Health $v$ Atkinson [2012] NZCA 184, [2012] 3 NZLR 456 at [133] and [134] per Ellen France J.

68 Butler and Butler "The Judicial Use of International Human Rights Law in New Zealand", above n 66, at 184. Allan and others noted that the number of references to the ECTHR is three times higher than the UNHRC: Allan, Huscroft and Lynch, above n 65, at 438.

69 Replies to the List of Issues to be Taken Up in Connection with the Consideration of the Fifth Periodic Report of New Zealand, above $\mathrm{n} 67$.

70 Butler and Butler The New Zealand Bill of Rights Act: A Commentary, above n 66, at [4.5.2] and [35.10.3]. Petra Butler referred to this approach as a "rhetorical device" to put the judgment in an international context as a justification: Petra Butler "The Use of Foreign Jurisprudence in New Zealand Courts" in Andrea Büchler and Markus Müller-Chen (eds) Private Law: national - global - comparative (Intersentia, Antwerp, 2011) 305 at 320 .

71 It is also implausible that New Zealand's courts feel obliged to go beyond a strictly textualist interpretative approach as a result of the non-binding nature of COs. Andrew Geddis contrasted this with the United Kingdom, where such an interpretative approach of courts can be grounded in the legally binding judgments of the ECTHR. Andrew Geddis "Which Is To Be The Master? Rights-friendly Statutory Interpretation in New Zealand and the United Kingdom" (2008) 25 Ariz J Intl \& Comp L 733 at 764-765.

72 It was even expected that the number of references to ECTHR would further increase given the growing reliance of New Zealand courts on United Kingdom courts deciding cases under the Human Rights Act 1998 (which incorporates the ECHR): Butler and Butler The New Zealand Bill of Rights Act: A Commentary, above n 66, at [3.6.48].

73 Butler and Butler "The Judicial Use of International Human Rights Law in New Zealand", above n 66, at 184. 
Grant Huscroft and Nessa Lynch argued that the UNHRC's lower number of citations is not surprising because, in the authors' view, it is common knowledge that the quality of decisions of the UNHRC is defective. This is because the UNHRC frequently merely enumerate facts and submissions while proclaiming the UNHRC's conclusion in a superficial way. ${ }^{74}$ Interviewees argued that the extent to which courts deal with HRTs and/or TB output depends on the degree to which they are invoked by lawyers. Lawyers are, however, reluctant to base their arguments on these sources when they are uncertain about not only the willingness of courts to take these considerations on board, but even about judges' knowledge of those considerations. ${ }^{75}$

\section{The NZHRC}

It is important to consider another domestic actor - the NZHRC - which was established in 1977 as an independent Crown entity. It advocates and promotes respect for human rights in New Zealand. Since the turn of the millennium, the NZHRC has become more active in relation to human rights in New Zealand as a result of the Human Rights Amendment Act 2001. ${ }^{76}$ That Act introduced a statutory duty to develop a national action plan for the promotion and protection of human rights in New Zealand. ${ }^{77}$ In September 2004 the NZHRC published the report Human Rights in New Zealand Today (2004 report) ${ }^{78}$ after extensive nationwide consultation, public opinion research and submissions, and the contributions of over 5,000 individuals, groups and organisations. In March 2005, the NZHRC released its Action Plan for Human Rights (2005 NZHRAP), containing 178 priorities for action. ${ }^{79}$ This action plan was not formally adopted by the Government. In 2011, the

74 Allan, Huscroft and Lynch, above n 65, at 438-439; David Erdos "Aversive Constitutionalism in the Westminster World: The Genesis of the New Zealand Bill of Rights Act (1990)" (2007) 5 ICON 343 at 367-368; Matthew SR Palmer "New Zealand Constitutional Culture" (2007) 22 NZULR 565 at 580 and 582.

75 The impression of Butler and Butler was that even within the legal community, knowledge about the ICCPR is "limited": Butler and Butler The New Zealand Bill of Rights Act: A Commentary, above n 66, at [4.5.2] and [35.10.3]. Illustrative of this is that there are also few lawyers (only Tony Ellis and John Steven Petris) who have brought more than one case before the UNHRC under the individual communications procedure. Since ratification of the Optional Protocol under the ICCPR on 26 May 1989, only 20 individual communications from New Zealand have been considered by the UNHRC.

76 The re-evaluation study expressed concern about the almost exclusive focus of the NZHRC on discrimination instead of the wider ambit of NZBORA rights and human rights: Cooper and others, above $\mathrm{n}$ 31 , at [8] and [9].

77 Section 5(2)(m).

78 NZHRC Human Rights in New Zealand Today: Ngā Tika Tangata O Te Motu, above n 2.

79 NZHRC The New Zealand Action Plan for Human Rights: Mana ki te Tangata - Priorities for Action (31 March 2005) 
NZHRC published an updated version of the 2004 report in which progress against the 178 priorities was measured (2010 report). ${ }^{80}$ The report formulated 30 further action points.

The NZHRC has become more involved in the reporting process and has started to integrate COs into its work. ${ }^{81}$ Since 2007 the NZHRC has submitted alternative information to various TBs, and representatives of the NZHRC have been present during dialogues with committees. ${ }^{82}$ The Government has also consulted the NZHRC to discuss draft versions of periodic State reports. ${ }^{83}$ Further, the NZHRC has increasingly referred to HRTs and COs in its submissions to Parliament. An illustration is the 2010 report, which includes significantly more references to COs and HRTs than the 2004 report and 2005 NZHRAP. While the latter two documents only referred to the CERD, ICCPR, ICESCR and CAT in rather general terms, the 2010 report discussed several other COs. Noteworthy is that the 2004 report and the 2005 NZHRAP did mention the CO of the UNCROC Committee in relation to corporal punishment in the introduction. In addition, the 2004 report discussed several of the COs of the UNCROC Committee and the comments in the shadow report of Action for Children and Youth in Aotearoa Incorporated (ACYA) more substantively in a specific chapter on children's rights. ${ }^{84}$ One explanation for this heightened attention to the UNCROC and COs is that the NZHRC cooperated with the Office of the Children's Commissioner (OCC) in the context of the action plan. ${ }^{85}$

80 NZHRC Human Rights in New Zealand 2010: Ngā Tika Tangata O Aotearoa, above n 11.

81 NZHRC Human Rights in New Zealand 2010: Ngā Tika Tangata O Aotearoa, above n 11, at 22-23; and NZHRC Tüi Tüi Tuituiā: Race Relations in 2010, above n 11, at 6.

82 A shadow report was submitted for CERD 2007, CAT 2009, ICCPR 2010, ICESCR 2012 and CEDAW 2012. Race Relations Commissioner [RRC] Joris de Bres was present during CERD 2007. The former Chief Human Rights Commissioner, Rosslyn Noonan, attended CAT 2009, UPR 2009 and UNCROC 2011. Equal Employment Commissioner Judy McGregor attended ICCPR 2010 (together with Sylvia Bell, NZHCR Principal Legal and Policy Analyst) and CEDAW 2012. The Chief Human Rights Commissioner, David Rutherford, and one senior staff member, Kendra Beri, attended the dialogue with the ICESCR Committee in 2012 .

83 Officials from the MOJ met with representatives of the NZHRC to discuss the draft of the fifth periodic report under ICCPR: Replies to the List of Issues to be Taken Up in Connection with the Consideration of the Fifth Periodic Report of New Zealand, above n 67, at [154]. In addition, the NZHRC contributed to the sixth CEDAW report of 2006: Sixth Periodic Report of New Zealand (continued) CEDAW/C/SR.806 (B) (2007) at [2].

84 The individual chapters of the 2004 report are accessible via NZHRC "Human Rights in New Zealand Today: Ngā Tika Tangata O Te Motu" (September 2004) <www.hrc.co.nz/report>. Chapter 4 deals with children's rights.

85 Interestingly, the only UN HRT that was explicitly mentioned in the 30 Action Points of the 2010 NZHRC report was UNCROC. Action Point 21 mentioned that legislation should reflect the obligations under UNCROC in relation to several legislative issues. 
In addition to the OCC, another Commissioner who deserves specific mention is the Race Relations Commissioner (RRC) who has started to monitor the implementation of the COs 2007 in the RRC's annual race relations report. ${ }^{86}$ Special mention should also been made of the role of the NZHRC under OPCAT and its function as a body for monitoring places of detention. Since 2007, the NZHRC has operated as the central preventative mechanism and coordinates and liaises with the other national preventative mechanisms (NPMs). ${ }^{87}$ An annual report is published about places of detention. It was acknowledged by interviewees that although NPMs have not yet developed into a mechanism that regularly monitors follow-ups to COs, the COs are nonetheless discussed during the regular roundtable meetings, which take place four-to-six times per year.

\section{E NGOs}

As stated in the introduction, the most important role for NGOs in the process of reporting is the submission of shadow reports to the TBs, in which NGOs criticise or alternatively complement the usually positive image sketched in the Government report. The involvement of NGOs has increased since the mid-2000s. Several new NGOs have become involved since 2000, while other NGOs have strengthened their participation in the process. Examples are the establishment of the the Aotearoa Indigenous Rights Charitable Trust in 2000 and the Human Rights Foundation Aotearoa (HRFA) in 2001. The latter was founded because it was felt that there was not really an existing NGO with a general human rights perspective. In addition, the New Zealand section of Amnesty International, the United Nations Children's Fund (UNICEF) and Save the Children created a domestic advocacy function five-to-10 years ago, bolstered their domestic advocacy work, and strengthened their involvement in the process of State reporting. An illustration of the enhanced participation is that no shadow reports were submitted to the UNHRC in 2002 and that for the ICESCR 2003, only a HRFA report about housing in New Zealand was submitted. ${ }^{88}$ By contrast, four and six shadow reports by New Zealand-based NGOs were submitted for ICCPR $2010^{89}$ and ICESCR $2012 .{ }^{90}$ Likewise, the

86 The reports of 2010 and 2011 assessed the level of implementation by and the response of the Government to all the COs 2007 in a table. The RRC has received assistance from the MOJ which helps in gathering an update of developments in relation to the COs from various departments each year. See Twentieth periodic reports of States Parties due in 2012: New Zealand CERD/C/NZL/20 (2012) at [14].

87 See above $\mathrm{n} 46$ for further information about NPMs.

88 Human Rights Foundation of Aotearoa New Zealand [HRFA] "Housing in New Zealand: Joint NGO submission in response to the New Zealand Government's Second Periodic Report to the Committee on Economic, Social and Cultural Rights" (April 2003) <www.humanrights.co.nz>.

89 Shadow reports were submitted by the following New Zealand-based NGOs or individuals: ACYA; Andrew Butler (as convener of the Human Rights Committee of the New Zealand Law Society); Peace Movement Aotearoa [PMA]; Barrister of the High Court Tony Ellis; Aotearoa Indigenous Rights Trust [AIR Trust]; and HRFA.

90 Shadow reports were submitted by the following New Zealand-based NGOs: AIR Trust; Amnesty International New Zealand; PMA; and HRFA. 
involvement of NGOs in relation to the CERD in terms of the submission of shadow reports has grown considerably since the - from an NGO point of view, successful - early warning procedure in relation to the FSA. $^{91}$ Several human rights lawyers have also become more active in recent times and have submitted shadow reports in relation to ICCPR 2010 and CAT 2009.92

NGOs can have a crucial role at the domestic level after the COs have been published. This domestic involvement of NGOs by way of consultation by the Government or lobbying for the implementation of COs has, however, been limited. Involvement of NGOs by the Government has not gone further than the circulation of a draft version of the State report for public comment. The Government admitted that the involvement of and regular consultation with civil society in the process of State reporting and follow-up to the COs could be improved. ${ }^{93}$ NGOs emphasised that they should be better informed at all phases of the reporting process and argued that their involvement in the follow-up phase is especially limited. ${ }^{94}$ Some COs have occasionally been referred to in submissions to parliamentary select committees or in media releases.

The picture is different for UNCROC and to a lesser extent CEDAW. For UNCROC there is a coalition of more than $100 \mathrm{NGOs,} \mathrm{individuals} \mathrm{and} \mathrm{families} \mathrm{interested} \mathrm{in} \mathrm{children's} \mathrm{rights} \mathrm{(ACYA),}$ whose objectives are all explicitly centred around UNCROC and the COs of the UNCROC Committee. $^{95}$ For UNCROC and CEDAW there were also consultation meetings between government officials and NGOs prior to the submission of the report or the dialogue as well as follow-up meetings on the basis of the COs. After the COs 2003, an UNCROC advisory group was set up which consisted of members of the OCC, NZHRC and representatives from NGOs (UNICEF,

91 No shadow report for CERD 2002 could be found. The report of the RRC in 2010 pointed to the greater involvement of civil society and increased input in the reporting process: NZHRC Tüi Tüi Tuituiā: Race Relations in 2010, above n 11, at 6. Besides the NGOs with a general human rights focus (PMA and HRFA) as well as children's rights (ACYA), the following Māori organisations submitted a shadow report to the CERD Committee in 2007: AIR Trust (made up of Māori individuals with close associations with their iwi); and the Treaty Tribes Coalition [TTC] Iwi (representing 15-20 per cent of the Māori population and a collective of four iwi Māori or indigenous peoples' authorities in Te Tai Tokerau).

92 Shadow reports were submitted by Tony Ellis and Antony Shaw, Barristers of the High Court, and lawyer Sonja Cooper. ACYA and HRFA also wrote a report.

93 Replies to the List of Issues to be Taken Up in Connection with the Consideration of the Fifth Periodic Report of New Zealand, above n 67, at [155].

94 See, for example, the 2007 CERD shadow report of the TTC, which stated that the Government had not sought engagement with Māori organisations as a follow-up to the COs 2002: TTC NGO 'Alternative Report' to the Committee on the Elimination of Racial Discrimination: Submission in response to the consolidated fifteenth, sixteenth and seventeenth periodic report of New Zealand (August 2007) at [5].

95 ACYA was the Action for Children in Aotearoa [ACA] until 2001. ACYA's objectives are: first, promoting the understanding and implementation of UNCROC; second, encouraging action on the basis of the COs of the UNCROC Committee; and third, submitting shadow reports to the UNCROC Committee. See ACYA "ACYA Aims and Objectives" (2005) <www.acya.org.nz>. 
Save the Children and ACYA) and which was coordinated by the Ministry of Youth Development (MYD). This group met at least twice a year between January 2004 and 2008. ${ }^{96}$

\section{F Media Coverage}

Almost all interviewees noted the lack of media coverage with respect to the process of State reporting. A quick scan of New Zealand newspapers shows that newspapers have primarily given attention to UNCROC, ICCPR and CAT and the COs of those respective Committees. ${ }^{97}$ In addition, there was also significant media coverage of the high profile cases of the repeal of s 59 of the Crimes Act 1961 and the FSA. ${ }^{98}$

\section{ASSESSING THE EFFECTIVENESS OF COS}

This Part examines the effectiveness of the COs. The starting point for this was an analysis of documents in which a reaction to the COs was provided, in particular the periodic State reports, ${ }^{99}$

96 The advisory group provided, advised on and assisted in UNCROC-related initiatives, such as the mid-2006 Forum, and it was offered the opportunity to provide feedback during the preparation of the State report: Third and fourth periodic reports submitted by States parties due in 2008: New Zealand CRC/C/NZL/3-4 (2010) at [13].

97 A search was performed of NZ newspapers using Newztext on The Knowledge Basket "Research Archives" <www.knowledge-basket.co.nz>. This digital archive contains major daily metropolitan and provincial newspapers, including the Dominion Post and the NZ Herald. The search was performed for the period from 1 September 1995 until 7 June 2012 with the following search terms: "Committee on Economic, Social and Cultural Rights" (nine results); "Covenant on Economic, Social and Cultural Rights" (23 results); "Committee on the Elimination of All Forms of Discrimination Against Women" (two results); "Convention on the Elimination of All Forms of Discrimination against Women" (46 results); "Committee on the Elimination of All Forms of Racial Discrimination" (zero results); "Convention on the Elimination of All Forms of Racial Discrimination" (25 results); "Committee Against Torture" (43 results); "Convention Against Torture" (53 results); "Committee on the Rights of the Child" (66 results); "Convention on the Rights of the Child" (373 results); "Human Rights Committee" (273 results); and "International Covenant on Civil and Political Rights" (106 results).

98 "United Nations" and "Foreshore and Seabed" (244 results); "United Nations" and "Smacking" (288 results); and "United Nations" and "Section 59" (122 results).

99 CAT COs 2004 were reproduced and responded to in a separate section: Fifth periodic reports of States parties: New Zealand CAT/C/NZL/5 (2004) at [293]-[346]. The short reaction to the CAT COs 1998 was also included in a separate section: Third periodic reports of States parties due in 1999 (Addendum): New Zealand CAT/C/49/Add.3 (2002) at [38]-[39]. The 2002 report to CEDAW started with a part in which the COs 1998 were replicated and responded to: Fifth periodic report of States parties: New Zealand CEDAW/C/NZL/5 (2002) at 14-24. A response to CEDAW COs 2003 and COs 2007 was given in a table appended to the subsequent reports: Sixth periodic report of States parties: New Zealand CEDAW/C/NZL/6 (2006) at Appendix I, and Seventh periodic report of New Zealand CEDAW/C/NZL/7 (2012). A short outline of the Government response to CERD COs 1995 and 2002 of less than one or two pages respectively was given in the introduction of the next reports. Some of the COs were also addressed in the body of these reports: Fourteenth periodic report of States parties due in 1999 (Addendum): New Zealand CERD/C/362/Add.10 (2001) at [3]; Consideration of Reports Submitted by States Parties Under Article 9 of the Convention: Concluding observations of the Committee on the Elimination of Racial Discrimination: 
annual progress reports of the UNCROC Work Programme, ${ }^{100}$ the internal MWA and MOJ briefings about CEDAW 2007, CAT 2009 and ICCPR 2010, as well as reports from the NZHRC and NGOs. This document analysis was complemented with interviews. Interviewees were first of all asked to give examples of effective COs themselves (see Table 2 below). Second, the author questioned the interviewees about policy and legislative changes or measures that in his view could have been potentially partly influenced or caused by COs.

Generally speaking, measures are not taken as a result of COs. This is, first of all, because the concerns and recommendations of the TBs often coincide with existing policy and legislative measures. The internal official MOJ briefing documents with responses to the COs of CAT 2009 and ICCPR 2010 provided that, except for two COs, ${ }^{101}$ none "require new work initiatives" and many can be implemented as "business as usual: that is, they can be successfully addressed as part of the Government's existing work programme". ${ }^{102}$ For a lot of these rather broadly formulated COs work was "already underway"103 for which the Government "is continually developing

New Zealand CERD/C/NZL/17 (2007) at [3]. Some of the CERD COs 2007 are referred to in a footnote. The following COs are, however, not explicitly addressed in the CERD report 2012: 11, 22, 24, and 27-39. Note that a separate reply was given to the COs in [14], [19], [20] and [23] of Twentieth periodic reports of States Parties due in 2012: New Zealand, above n 86. Something similar was done in relation to the ICESCR COs 1993: Second periodic reports submitted by States parties under articles 16 and 17 of the Covenant: New Zealand E/1990/6/Add.33 (2001) at [48]. The ICESCR report 2009 only referred to three of the COs 2003: Third periodic reports submitted by States parties under articles 16 and 17 of the Covenant: New Zealand E/C.12/NZL/3 (2011) at [18]-[27], [167] and [360]. A summary of the reaction to seven of the ICCPR COs 1995 was provided in pt 2 of the 2001 report while a more substantive reaction to those COs and some others was provided in the main body: Fourth periodic report of States parties due in 1995: New Zealand CCPR/C/NZL/2001/4 (2001) at [53]. Only five of the ICCPR COs 2002 were mentioned in the main body of the report: Fifth periodic reports of States parties: New Zealand, above $\mathrm{n} 2$.

100 This programme and subsequent annual progress reports to Cabinet are available on the Ministry of Social Development website <www.msd.govt.nz>.

101 The only CO that "would require active steps if they are to be addressed in full" had to do with the withdrawal of reservations to the ICCPR. One interviewed government official, however, held that the review would have been completed in the next five years anyway. Officials proposed that it be conducted by MOJ and MFAT in order to be completed before 31 March 2012. Nonetheless, this review has been deferred: Illingsworth, above $\mathrm{n}$ 14. The other $\mathrm{CO}$ was the extension of the mandate of the NZHRC to receive complaints of human rights violations in the context of immigration. MOJ officials recommended that the Minister of Justice not revise the issue at that time, because the Immigration Act 2009 (preventing the NZHRC from doing so) had been only recently implemented: "Response to Concluding Observations of the United Nations Human Rights Committee" (11 March 2011) HUM-06-02-03 at [6], [14] and [16] (Obtained under Official Information Act 1982 Request to the MOJ).

102 The briefing, for example, outlined steps taken before CAT 2009 to ensure that sufficient capacity was developed for prisons which "should go some way to addressing" CAT COs 2009: "Responses to Recommendations Arising from the Convention Against Torture Presentation" (26 August 2009) HUM-0614-02 at [3], [9], [21] and [71] (Obtained under Official Information Act 1982 Request to the MOJ).

103 The first UNCROC Work Programme divided the COs into two types: issues in relation to which work was "already underway" and issues that called for "new work". The programme aimed to minimise the number 
strategies". 104 Officials argued that the concerns of TBs, which frequently flow out of self-critical comments of the Government, were already known and were hence being addressed by the Government. ${ }^{105}$

Second, other COs were dismissed or not acted upon because they were "likely to be difficult to respond [to]" or because "the intervention proposed by the Committee is not preferred by New Zealand". ${ }^{106}$ These COs are found to be politically unacceptable or not feasible budget-wise. Examples are the use of tasers, the privatisation of prisons, the entrenchment of the NZBORA and the status of the Treaty of Waitangi. In these cases, domestic policy considerations take precedence. The Government consequently decides not to take further action at that point in light of "a lateral approach [that] may be taken to respond" to the COs. ${ }^{107}$ Usually the response to the COs in this context implies that TBs had made an incorrect appraisal and that a small number of COs "arose because of a misunderstanding of the legal frameworks" (see Part IV). ${ }^{108}$

A third category includes COs that have been effective. Tables 2 and 3 show an overview of the COs that have played a role in New Zealand's political policy and law-making processes. In some instances COs were a necessary cause of policy and law-making, although they were often still not sufficient in themselves (see Table 2). Usually a "rich combination of influences" is still needed to

of issues in the latter category by developing responses to the COs "as part of existing work wherever possible": Second periodic reports of States parties due in 2000: New Zealand CRC/C/93/Add.4 (2003) at [20]-[22].

104 These strategies are "ongoing" and "long term". They include reducing social inequalities in wellbeing, giving assistance to refugee children, and reducing child abuse and health and education disparities. The milestones in relation to these items in the UNCROC Work Programme are "to report to the Government on a regular basis", the "provision of updated information", "ongoing work" or "further progress" (items 9-11, 13, 16-17, and 19). Note that this research does not address the COs in relation to the OPCAT under UNCROC, which are addressed in items 21-27.

105 The response to CAT COs 2009 stated that: "none of the matters raised are a surprise": "Responses to Recommendations Arising from the Convention Against Torture Presentation", above n 102, at [5].

106 "Overview of the recommendations of the Committee on the Elimination of Discrimination Against Women" (31 March 2008) PIN-02-2007 at [14]-[16] (Obtained under Official Information Act 1982 Request to the MOJ (transferred to the MWA)).

107 Ibid.

108 The briefing stated that the CAT Committee's concerns about the discretion of the police to prosecute acts of torture were "misplaced". Likewise, a legislative amendment to exclude the admissibility of evidence obtained by torture was not necessary because this was already guaranteed by the Evidence Act 2006: "Responses to Recommendations Arising from the Convention Against Torture Presentation", above n 102, at [3], [50] and [62]. 
bring about a change, as was, for example, the case with the repeal of s 59 of the Crimes Act 1961. ${ }^{109}$

Table 2: Overview of COs That Were a Conditio Sine Qua Non

\begin{tabular}{|l|l|c|}
\hline Policy or legislative measure & CO & $\begin{array}{c}\text { Number of } \\
\text { interviewees who } \\
\text { mentioned the CO as } \\
\text { effective }\end{array}$ \\
\hline - $\quad$ Repeal of section 59 [private members' Bill] & UNCROC 97/ 03 \\
- $\begin{array}{l}\text { Education of unlawfully present children } \\
\text { - Measures to address inconsistencies in age limits }\end{array}$ & UNCROC 97/03 & 16 \\
\hline - Public education campaign on s 59 & UNCROC 97/03 & 3 \\
\hline Authongthening independence of Police Conduct & CAT 09 & - \\
\hline Translation CEDAW in Māori & CEDAW 98 & - \\
\hline
\end{tabular}

In other cases, COs have not been an essential condition, but were, nonetheless, an important factor in the policy or legislative measures (see Table 3). Government officials noted that some COs have raised awareness of or put an issue higher on the agenda, such as the issue of child poverty and the over-representation of Māori in prison. In addition, COs have also assisted one side in the debate by supporting or strengthening policy arguments. In the case of the FSA repeal, there was, for instance, already domestic opposition prior to the 2005 early warning decision of the CERD, but the decision, and the COs 2007, became a factor in and galvanised the domestic debate.

Table 3: Overview of COs as an Important Contributory Cause

\begin{tabular}{|l|l|c|}
\hline Policy or legislative measure & CO & $\begin{array}{c}\text { Number of } \\
\text { interviewees who } \\
\text { mentioned the CO as } \\
\text { effective }\end{array}$ \\
\hline $\begin{array}{l}\text { Measures to avoid age mixing in prison } \\
\text { (reservation art 37(c) UNCROC) }\end{array}$ & UNCROC 97/03 & 8 \\
\hline
\end{tabular}

109 Sue Bradford MP, who introduced the private members' Bill, explained that she was "stirred into political action by the recommendations that the UN Committee on the Rights of the Child made on two occasions": Wood, Hassall and Hook, above n 43, at 204. See also 33, 176, and 201. 
- Child poverty/ Green Paper for vulnerable children

- Strengthening employment position of children (reservation art 32 UNCROC)

- Collection of data budget allocation

- Youth suicide

- Young Persons and their Families Bill (No 6)

- Strengthening OCC

- Human rights training Corrections Department

- Inspections Ombudsman concerning double bunking

- Incorporation non-refoulement in Immigration Act 2009

- $\quad$ Repeal FSA 2004

- Over-representation of Māori in prison

- Introduction of paid parental leave

- Withdrawal reservation CEDAW concerning CEDAW 94/98 women in armed forces [private members' Bill]

\begin{tabular}{|l|l|} 
UNCROC 11 & 5 \\
UNCROC 97 & 4 \\
UNCROC 97/03 & 2 \\
UNCROC 97 & 2 \\
UNCROC 97/03 & 2 \\
UNCROC 97/03 & 1 \\
\hline CAT 09 & 2 \\
CAT 09 & 1 \\
CAT 04 & - \\
\hline CERD 04/ 07 & 7 \\
CERD 07 & 6 \\
\hline CEDAW 94/98 & 4 \\
CEDAW 94/98 & \\
\hline
\end{tabular}

The tables show that the majority of effective COs were from the UNCROC Committee. This is not surprising in light of the UNCROC Work Programme which primarily outlined measures taken as a result of the COs in relation to the withdrawal of reservations, age inconsistencies and corporal punishment. The reservations were "key items" and received "high priority". ${ }^{110}$ In addition, as the previous Part showed, there has been more lobbying on the basis of UNCROC by NGOs and the OCC. The UNCROC and the COs were also deliberately used by NGOs to inform their advocacy, and used as an awareness, information and lobbying tool. As will be explained in the next section, MYA officials also had more interest in and commitment towards UNCROC and addressing COs. They were dedicated to working on the issues, and the UNCROC and COs were used to advance the children's agenda and to secure political support via the UNCROC Work Programme.

There are also several CAT Committee COs that have been effective. There are several factors that could have contributed to this. First, as was argued before, one important reason for the 
heightened attention given to CAT and the COs was the ratification of OPCAT on 14 March 2007. Interviewees observed that the ratification of OPCAT made a big difference in New Zealand because of the establishment of NPMs that monitor places of detention in light of OPCAT. The annual OPCAT report 2012 observed "positive impacts and practical improvements as the result of monitoring". ${ }^{111}$ It could be argued that the NPMs with their regular roundtable meetings facilitate follow-ups to CAT COs as well.

\section{EXPLAINING THE (IN)EFFECTIVENESS OF COS}

\section{A Factors Related to the TB System}

It was argued by several interviewees that the COs only have an impact and are only effective when the TBs are credible. Some government officials held that only a small minority of TB members are competent and knowledgeable. ${ }^{112}$ The criticism was directed at all TBs across the board, although some committees or sessions were considered better than others. ${ }^{113}$ Several aspects were mentioned that especially undermine the credibility and authority of the TBs and also explain why often hardly any notice is taken of COs.

First, the factual mistakes and inaccuracies in some of the COs were mentioned. The CAT COs 1998, for example, recommended the completion of an investigation into the events at Mangaroa Prison, but this had already been completed and the results were annexed to the 1997 State report. The Committee expressed regret for this mistake. ${ }^{114}$ At other times, the TBs have been more reluctant to allow for the correction of these factual inaccuracies. ${ }^{115}$ An NGO representative also noted that some UNCROC COs 2011 were plainly incorrect. An example was the concern that "the judiciary uses a punitive approach more often than a restorative approach".

A second aspect was the over-reliance on NGO input without giving due consideration to the alternative viewpoints of the Government. Both government officials and NGO representatives

111 NZHRC Monitoring Places of Detention, above n 46, at 2.

112 Some government officials held that the criticism should be directed at the member States that nominate and elect TB experts and also provide the TB's resources.

113 The sessions and committees that were considered better or above average were ICCPR 2002 and ICCPR 2010, UNCROC 2003 and CAT 2004 and 2009 (as they had more technical experts and detailed questioning on more practical matters). Government officials were more critical about CERD 2005, CEDAW 2003 and 2007 and especially ICESCR 2003 and 2012 and CERD 2002.

114 Third periodic reports of States parties due in 1999, above n 99, at [38]; Second Periodic Report of New Zealand (continued) CAT/C/SR.334 (1998) at [4].

115 One example mentioned was the ICESCR CO 2012, which held that discrimination against persons with disabilities in relation to the provision of accommodation is not explicitly prohibited, although this is provided for in the Human Rights Act 1993 and there is case law on point as well: Concluding observations of the Committee on Economic, Social and Cultural Rights: New Zealand E/C.12/NZL/CO/3 (2012) at [13]. 
noted the elevated influence of NGOs on the Committees' questions and COs. NGO representatives were obviously content with this. Government officials, however, were rather critical about TBs, primarily criticising the use of NGO information without verification. A lot of questions and COs came from NGOs who were said to have used incorrect or outdated information. The internal MWA briefing about the CEDAW COs 2007 hence stated that "some criticism ... is unbalanced. In particular, some of the criticism gives undue weight to the input of non-governmental organisations without any supporting evidence."116

Third, interviewees noted the plain misunderstanding of the domestic context visible in the questions of TBs and their COs. Although government officials acknowledged that the amount of reading is considerable, they expressed their disappointment in the inadequate preparation on the part of the TBs. Almost all government officials lamented the complete lack of understanding of the committees, with some individual exceptions regarding the structure and make-up of New Zealand's society and its democratic processes. Don MacKay, the former Deputy Secretary of MFAT and Permanent Representative to the UN in Geneva, who was part of the delegation in 2003 (CEDAW) and head of the delegation in 2007 (CERD) and 2009 (CAT), argued that TBs do not have the background or expertise to deal with "huge policy issues" that have "huge significance for states". 117 TBs were said to inadequately grasp subtle but essential details. ${ }^{118}$ Several officials, for example, mentioned that some TB members did not seem to understand the Treaty of Waitangi and indigenous issues and were under the impression that Māori lived in reservations. ${ }^{119}$ They referred to questions as to whether Māori need the permission of the court to marry. During CEDAW 2003 there was a question concerning whether women are allowed to own property, which an official compared to asking whether there is electricity in the Netherlands. ${ }^{120}$ Some officials also noted the odd and irrelevant questions about "rural women". ${ }^{21}$ The COs are also said to show similar

116 "Overview of the recommendations of the Committee on the Elimination of Discrimination Against Women", above n 106, at Appendix B.

117 Don MacKay "The UN Covenants and the Human Rights Committee" (1999) 29 VUWLR 11 at 16.

118 With respect to the individual communication of Rameka, Claudia Geiringer pointed to the "major deficiencies" in the understanding of New Zealand's complex sentencing regime by the UNHRC, which she attributed to limited resources and the fact that TB members are not remunerated: Claudia Geiringer "Case Note: Rameka v New Zealand" (2005) 2 NZYIL 185 at 196-199.

119 See, for example, the reference of Mr Sadi to "the refusal of the Māori community to integrate or assimilate" and of Mr Ceausu, who said that "communities could become integrated": Second periodic report of New Zealand E/C.12/2003/SR.11 (2004) at [36] and [40]. See also the similar comments of Mr Caughley at [42].

$120 \mathrm{Ms}$ Gnancadja "stressed the need to implement practical measures to protect the interests of rural women, including their property and inheritance rights." Ms Dyson stated in her answer that equal rights to property were already legally guaranteed: Fifth periodic report of New Zealand CEDAW/C/SR.625 (2003) at [26] and [33].

121 Ibid, at [23] and [26]. 
misunderstandings and are, hence, difficult to implement. The MWA briefing held that "it is disappointing that some of the recommendations do not fully reflect New Zealand's domestic situation." 122 An example given concerned access to sewage systems "in rural and remote areas". ${ }^{123}$ It was also said that the UNCROC COs 2011 (recommending that domestic legislation relating to children supersede Māori customary law) show a lack of understanding of the profoundness of Māori issues. ${ }^{124}$

Although the number of "extreme" questions and odd COs might be limited, interviewees held that these "stupid" questions and COs put the delegation off. Some officials argued that if only one TB member said something outlandish, this would call into question the credibility of the whole Committee. Politicians can also easily dismiss the process, as was highlighted by the quotations in Parts I A and I B. Some interviewees expressed a genuine concern that such COs generate ignorance and undermine the other COs that were better targeted at these areas of expertise. They held that even if these COs include a couple of reasonable recommendations, they can and will be easily dismissed altogether. This is because politicians, the media, some government officials, and general public perception, focus on these particular COs to discredit the rest of the COs. The limited legitimacy and persuasiveness of the CEDAW Committee in the view of government officials thus negatively affects the Government's willingness to act upon the COs. As argued in the previous Part, another explanation for the ineffectiveness of COs is that they are often rather broad and do not outline a specific course of action. Because COs are undetermined, they often simply coincide with measures already in place without a causal relationship between them.

\section{B Political and Cultural Factors in New Zealand}

\section{Limited domestic mobilisation}

As was outlined in the previous Parts, one important explanation for the limited effectiveness of many COs, especially those from the UNHRC and ICESCR Committees, is the absence of domestic mobilisation and the invisibility of COs. Because Parliament, NGOs and the media barely pay attention to or lobby on the basis of COs, the Government can easily get away with doing nothing.

\section{The negative attitude of government officials towards the value of reporting}

Another explanation for the limited impact and effectiveness of the State reporting process is the attitude of government officials. The process has been approached as a compliance exercise instead

122 "Overview of the Recommendations of the Committee on the Elimination of Discrimination Against Women", above n 106, at Appendix B.

123 Concluding observations of the Committee on Economic, Social and Cultural Rights: New Zealand, above $\mathrm{n}$ 115, at [24]. See also the references to rural women in Concluding Comments of the Committee on the Elimination of Discrimination against Women: New Zealand CEDAW/C/NZL/CO/6 (2007).

124 Concluding observations: New Zealand CRC/C/NZL/CO/3-4 (2011) at [11] and [55]. 
of a learning opportunity. ${ }^{125}$ Almost all government officials interviewed lamented the burden of reporting, as well as the resulting duplication and overlap between the several reports. They held that the process is time-consuming and a "demanding chore", especially for a small country like New Zealand. Officials argued that the process was therefore not given the priority it should have been. Writing or compiling parts of the State report has often been entrusted to junior officials, which explains why reporting does not have that much of an impact. Coordinating government departments noted a difficulty in collecting information on time from departments that are more focused on domestic priorities.

Several government officials mentioned that the picture was different for the 1997 and 2003 UNCROC reports, which were coordinated by the MYA and MYD. ${ }^{126}$ The primary reason for this is that the UNCROC State reports are coordinated by a "population agency" with an entrenched interest in reporting. ${ }^{127}$ There was more interest in and enthusiasm for reporting under UNCROC and officials tried to give a fair picture and acknowledge deficiencies in the reports. The 2001 report, for example, mentioned quite extensively the criticisms expressed in NGOs' submissions. MYA and MYD have also used the process of reporting as a way to foster "dialogue" and work together with NGOs, the OCC and the NZHRC as well as children and young people themselves. ${ }^{128}$

There are several reasons for the greater enthusiasm shown by the MYA and MYD and their officials towards reporting. First of all, many MYA officials had a personal interest in UNCROC and some were keen children's rights advocates themselves. ${ }^{129}$ They tried to push the children's rights agenda in their interactions with other departments. Second, officials from the MYA acknowledged that UNCROC was useful in helping to advance domestic issues, because UNCROC was consistent with what the MYA was advocating for, including youth development, youth

125 This despite that fact that several officials stated that they considered the process of reporting potentially important. They argued that it provokes useful reflection and that it focuses officials' minds on important domestic human rights issues. Other officials held that it provides an oversight of human rights in New Zealand or that it serves as a benchmarking exercise. Government officials were, however, sceptical about the extent to which the process of reporting realised this potential in practice.

126 In October 2003, MYA and MYD merged with the youth policy functions of the MSD in a new MYD division within the MSD, in order to ensure better coordination: Second periodic reports of States parties due in 2000: New Zealand, above n 103, at [151]; Second periodic report of New Zealand CRC/C/SR.896 (2003) at [36].

127 According to the MWA's statement of intent, one of the three tasks of the MWA is to manage New Zealand's international obligations in relation to the status of women. CEDAW has sometimes been mentioned explicitly in this context. Nonetheless, the most recent Statement of Intent 2012-2015 did not refer to CEDAW at all: MWA Statement of Intent 2012-2015 (2012).

128 Third and fourth periodic reports submitted by States parties due in 2008: New Zealand, above n 96, at [19].

129 One former MYA official, Andy Jamison, was, for example, a member of the establishment group of the NGO End Physical Punishment of Children [EPOCH]. 
participation and children's rights. The process of State reporting was thus used in a strategic way to realise domestic priorities. As the smallest, and according to some, "the least listened to" ministry, reporting was one of the biggest and most visible things they were required to do. The UNCROC and the COs gave leverage and strengthened policy arguments, were some of the tools used to achieve concrete changes, but also served to stimulate a wider understanding of children's rights and to develop a framework for considering them in policy-making. ${ }^{130}$ The UNCROC Work Programme was primarily driven from the bottom-up by government officials. A number of interviewees noted the lower priority given to UNCROC and reporting, since responsibility for UNCROC shifted from the MYD to the MSD in 2008. ${ }^{131}$

\section{Complacency in an ideal human rights situation}

Several interviewees argued that there is a genuine aspiration to act in accordance with international law and that this favours compliance with COs. In New Zealand there is a true commitment to multilateralism and an internationalising impulse to be part of the wider world. ${ }^{132}$ New Zealand (and especially Labour Party) politicians emphasise their internationalist tradition. They like to see themselves as the "good international citizen" and wish to act in accordance with international law. There is real pride in New Zealand at being part of and contributing to advances in the international legal system, such as the International Court of Justice judgments relating to nuclear weapons. ${ }^{133}$ The Government highlighted, for example, that "New Zealand was one of a small number of States which presented concrete proposals to include 'respect for' and 'the

130 MYA took several initiatives to improve the integration of UNCROC in governmental processes and has used the process of reporting as a basis for doing so: Second periodic reports of States parties due in 2000: New Zealand, above n 103, at [108].

131 Interviewees argued that reporting is approached more as a compliance exercise, in line with the other treaties. Another difference with the 2000 State report was that the former was a big publication that was disseminated widely, while the 2008 State report was merely put online. Interviewees considered that although MYD is still nominally present, MYD is swallowed up by MSD and does not have a high profile. MYD is currently sitting within the Social Services Policy Group and is especially working in the area of child abuse while also making sure that young people's views are reflected in government decisions. See Ministry of Social Development "Pathway to Partnership Steering Group: member profiles" <www.msd.govt.nz>.

132 Treasa Dunworth "Lost in Translation: Customary International Law in Domestic Law" in Hilary Charlesworth and others (eds) The Fluid State: International Law and National Legal Systems (The Federation Press, Sydney, 2005) 136 at 141-142; see also Hon Phil Goff "International Institutions and Governance: a New Zealand Perspective" (2004) 1 NZYIL 1.

133 In 1973 and 1995, New Zealand and Australia brought proceedings against France: Don MacKay "Nuclear Testing: New Zealand and France in the International Court of Justice" (1995) 19 Fordham Intl L J 1857. 
protection of' human rights as a principle of the United Nations". ${ }^{134}$ There is a strong belief in New Zealand that the country is playing a leading role in the world when it comes to human rights. ${ }^{135}$

The desire to comply with international law and COs must, however, be understood in light of the strong perception among government officials and ministers that New Zealand is already in compliance with the HRTs. The logic is that New Zealand only becomes a party to international treaties when existing domestic legislation, policy and practice are in accordance with the treaty concerned. ${ }^{136}$ This means that legislation and policies are "reviewed at length" to be sure that they meet the obligations under the relevant treaty prior to the decision to accede to it. ${ }^{137}$ Several interviewees also referred to the belief of government ministers and officials that in New Zealand the right thing is being done. ${ }^{138}$ Many officials believe that New Zealand policy is already in line with what human rights laws require. The logic runs that if there is a good policy reason to do something, it is inevitably consistent with human rights. Former Attorney-General and Prime Minister, Sir Geoffrey Palmer, observed that: ${ }^{139}$

\footnotetext{
New Zealand has always prided itself on respecting fundamental human rights ... the rhetorical political tendency was to say that New Zealand always honoured fundamental human rights without looking to see whether the claim was valid. Too often it was not. Administrative convenience, a tendency to trust the state and the use of its powers, and a homogenous political culture with a unicameral legislature made New Zealand in historical terms rather self satisfied and uncritical about rights.
}

134 Rt Hon Helen Clark "Foreword" in MFAT New Zealand Handbook on International Human Rights (Wellington, 2008) 1 at 5-6. New Zealand also played "an important role" in the drafting and adoption of the Universal Declaration of Human Rights with a prominent role for economic, social and cultural rights and subsequent negotiations for ICCPR and ICESCR: see Butler and Butler The New Zealand Bill of Rights Act: A Commentary, above n 66, at [3.6.2] and [3.6.23].

135 The delegation stressed during the dialogue with the ICESCR Committee in 2012 that it played this role in developing the international human rights legal framework. It stated that "New Zealand is proud of its record as a contributor, nationally and internationally, to human rights". It underlined in this context that it was a founding member of the UN: Debbie Power "Introductory Remarks" (Presentation of New Zealand's 3rd periodic report to the Committee on Economic, Social and Cultural Rights, Palais Wilson, Geneva, 4 May 2012) at 4 and 9. See also Hopkins in Shelton, above n 59, at 430.

136 Second periodic report of New Zealand (continued) CAT/C/SR.876 (2009) at [5] and [6]; Sixth periodic report of States parties: New Zealand, above n 99, at [18].

137 Reports submitted by States parties in accordance with articles 16 and 17 of the Covenant: New Zealand E/C.12/1993/SR.24 (1993) at [30] and [38].

138 Claire Charters argued that New Zealanders have "an exaggerated, and possibly misguided, sense of their own benevolence that impairs their ability to critically assess their ability to protect rights": Charters, above n 54, at 652 .

139 Geoffrey Palmer "Foreword" in Butler and Butler The New Zealand Bill of Rights Act: A Commentary, above n 66, at [39]. 
This view has led to a "complacency in a seemingly ideal situation", which the CEDAW Committee cautioned against. ${ }^{140}$

Treasa Dunworth observed that the "internationalising impulse" must be contrasted with an indigenous self-governance inclination, which is, for instance, visible in the reaction to the CERD decision with respect to the FSA (Part I A). ${ }^{141}$ Hilary Charlesworth and others labelled this as "Janus-faced": a sentiment proven by a country that is a fervent supporter of human rights at the international level, yet which is more careful in its domestic implementation. ${ }^{142} \mathrm{~A}$ factor that also downplays the internationalising impulse is that the costs of not complying with COs (in terms of domestic or international embarrassment for being seen as "anti-rights") have sometimes been minimal. ${ }^{143}$ Likewise, Janet McLean argued that naming and shaming is not effective when the greatest amount of individual communication comes from countries with a relatively good record of human rights protection. ${ }^{144}$

\section{The reluctance to accept external interference and criticism}

Several interviewees mentioned that New Zealanders do not like to be criticised, especially by officials from other jurisdictions. ${ }^{145}$ This point of view was, during interviews, said to be particularly voiced by politicians and ministers and less by government officials. Then Deputy Prime Minister Dr Cullen, for example, held that the Special Rapporteur on the rights of indigenous peoples': ${ }^{146}$

... raft of recommendations is an attempt to tell us how to manage our political system. This may be fine in countries without a proud democratic tradition, but not in New Zealand where we prefer to debate and find solutions to these issues ourselves.

140 MWA "Panui" (September 2003) <www.mwa.govt.nz> at 3.

141 Dunworth in Charlesworth and others The Fluid State: International Law and National Legal Systems, above n 132, at 141-142.

142 The term "Janus-faced" was used by Charlesworth and others in relation to Australia. Australia responded to TBs in a similar way as New Zealand responded to the CERD decision with respect to the FSA: Charlesworth and others No Country is an Island: Australia and International Law, above n 24, at 65 and $82-88$.

143 Geddis "Which Is To Be The Master? Rights-friendly Statutory Interpretation in New Zealand and the United Kingdom", above n 71, at 765.

144 McLean "The New Zealand Bill of Rights Act 1990 and Constitutional Propriety", above n 53, at 24; MacKay "The UN Covenants and the Human Rights Committee", above n 117, at 14.

145 See Wood, Hassall and Hook, above n 43, at 57.

146 Hon Dr Michael Cullen MP "Response to UN Special Rapporteur Report" (press release, 4 April 2006). 
Hon Chester Borrows MP (National Party) referred to New Zealand's "autonomy and sovereignty as a nation" as a justification for not acting in accordance with UNCROC. ${ }^{147}$ Gerry Brownlee MP (National Party) stated that "New Zealanders don't need to be told by the UN what it means to be a Kiwi. Fair-minded Kiwis will reject these statements outright, because they know them to be untrue." 148

There is, thus, considerable resentment towards bodies composed of countries with less than perfect human rights records. Hassall referred to deeply held fears of losing sovereignty and autonomy and a reluctance to grant the UN - which is seen by the public as "an agency of doubtful politics, ignorance of local issues and lack of accountability" - too much power. ${ }^{149}$ Several interviewees noted that intimating that something needed to be done simply because the UN or a TB says so is not very effective or helpful in realising a policy change. ${ }^{150}$ This discourse reflects what Hilary Charlesworth and others termed "popular and political anxiety about unwarranted 'intrusions' into Australian 'sovereignty' and domestic decision-making". 151

Charlesworth and others, however, concluded that a government is not so much concerned with external interference with domestic affairs, but with any entity that disputes government policy on the basis of human rights. The authors showed that the Australian Government reacted in similar ways to pronouncements of domestic courts in the field of human rights. ${ }^{152}$ This is also the case in New Zealand. Matthew Palmer noted that "suspicion of judges' ability to frustrate the will of a democratically elected government taps into a deep root in the New Zealand national constitutional culture." 153 There is an ideological preference for and trust in a powerful government with a strong presumption that if the government wants to do something, they should be allowed. Matthew Palmer

147 (14 July 2011) 674 NZPD 20146.

148 Gerry Brownlee MP "UN assumptions biased presumptions" (press release, 25 November 2005)

149 Ian Hassall and Emma Davies "The Use and Misuse of the UN Convention" (2003) 7 Childrenz Issues 34 at 34-35.

150 For this reason, advocates of the repeal of the defence allowing parents to use corporal punishment did not frame their argument in terms of children's rights and entitlements, but connected their argument to the positive outcomes for parents and society: Wood, Hassall and Hook, above n 43, at 57.

151 This anxiety was said to be present among the higher levels of the Australian judiciary and executive. In New Zealand, the judiciary is relatively open to international law and government officials seem less sceptical and more receptive as well: Charlesworth and others No Country is an Island: Australia and International Law, above n 24, at 2. Treasa Dunworth also noted that the indigenous self-governance impulse is stronger in Australia: Dunworth in Charlesworth and others The Fluid State: International Law and National Legal Systems, above n 132, at 141-142.

152 Charlesworth and others No Country is an Island: Australia and International Law, above n 24, at 91 and 99.

153 Matthew SR Palmer "New Zealand Constitutional Culture", above n 74, at 578, 581 and 585-586. 
even held that there is a "strong streak of authoritarianism" in New Zealand. ${ }^{154}$ Geoffrey Palmer further referred to the "tendency to trust the state". 155

\section{The limited knowledge and salience of rights}

Another explanation for the limited impact and effectiveness of HRTs and the process of State reporting is the limited understanding of human rights or the NZBORA among the wider public. ${ }^{156}$ Moreover, as several interviewees and scholars noted, the "language of rights" does not work in New Zealand. ${ }^{157}$ The American scholar Kerry Hunter observed that in contrast to the United States, there is less litigation in New Zealand and fairness is emphasised over legality. In this context, he pointed to the numerous extra-judicial institutions in New Zealand. ${ }^{158}$ There is an idea that an appeal to rights is "a last resort of people pursuing an unworthy agenda". 159 The NZBORA is perceived by the general population as a "drunk drivers' charter" which does not "offer something to all New Zealanders"; or a criminals or rogues charter. ${ }^{160}$ One example is the announcement that aggrieved red-zone residents in earthquake-hit Christchurch were to take their case to "the UN". The majority of reactions to this were dismissive and the residents were labelled by some as selfish, arrogant or "spoilt children stamping their feet" and contrasted with "people starving, wars, killing" or "concentration camps" in other countries worse off. ${ }^{161}$

One might wonder whether these country-specific explanations for the limited effectiveness of COs are typical for New Zealand or whether they also hold true for other western liberal democracies. Similar research showed that the first three factors listed above are also present in the

154 Matthew SR Palmer "New Zealand Constitutional Culture", above n 74, at 565 and 575-576.

155 Geoffrey Palmer as cited in Butler and Butler The New Zealand Bill of Rights Act: A Commentary, above $\mathrm{n}$ 66 , at [39].

156 Education in schools on human rights is limited. In addition, Butler and Butler held that "Bill[s] of Rights do not rate here": Butler and Butler The New Zealand Bill of Rights Act: A Commentary, above n 66, at [2][3].

157 Claire Charters referred to the inheritance of the unwritten constitution and the dislike of the Treaty of Waitangi as possible explanations: Charters, above n 54, at 652 .

158 Kerry L Hunter "American Constitutionalism an Impediment to the Pursuit of Fairness? Lessons from New Zealand Political Culture" (2009) 5 Policy Quarterly 44.

159 Wood, Hassall and Hook, above n 43, at 55.

160 Cooper and others, above n 31, at [53]. See also Andrew Butler "Judicial Review, Human Rights and Democracy" in Grant Huscroft and Paul Rishworth (eds) Litigating Rights: Perspectives from Domestic and International Law (Hart Publishing, Oxford, 2002) 47; Butler and Butler The New Zealand Bill of Rights Act: A Commentary, above n 66, at [35.9.2].

161 See the reactions to the announcement at Lois Cairns "Red-zone residents threaten UN action" Stuff (10 June 2012) <www.stuff.co.nz>. 
Netherlands and Finland, but that the latter two might be typical for New Zealand only. ${ }^{162}$ In the Netherlands and Finland, human rights are invoked by a wide range of actors and have become an integral part of the domestic political decision-making process. Moreover, human rights are part of a popularised discourse and are valued positively by the population. Politicians, journalists and columnists all talk about human rights in a favourable way and human rights experts are treated as "doing something good" by "always being on the side of the weak ones". ${ }^{163}$ In the Netherlands and Finland, government officials, judges and the great majority of the public are also accustomed to (and accept that) political and legal decision-making is constrained by international and European law, especially European Union (EU) and ECHR law. Likewise, even courts in the United Kingdom have been more willing than their New Zealand counterparts to adjust the doctrine of parliamentary sovereignty on the basis of the United Kingdom's membership of the EU and ECHR. ${ }^{164}$ The difference between New Zealand and these European countries can primarily be explained by the absence of a truly effective external check for New Zealand in line with the ECHR and ECTHR. The Finnish experience illustrates that it was the rather late ratification of the ECHR in 1990 that was a "turning point" and led to a growing profile and culture of human rights with increased attention paid by both the Government and Parliament to European human rights. ${ }^{165}$ An effective external check for New Zealand is, however, not foreseeable in the near future since the ineffectiveness of the UN human rights TBs seems inherent in the system (Part III A). ${ }^{166}$

162 Krommendijk "Just 'a little UN Committee' or important policy driver? The impact and effectiveness of the CEDAW Committee in New Zealand", above n 1; and Krommendijk "The Impact and Effectiveness of State Reporting under the Women's Convention: The Case of the Netherlands" in Ingrid Westendorp (ed) The Women's Convention Turned 30: Achievements, Setbacks, and Prospects (Intersentia, Antwerp, 2012) 487.

163 These statements were made in relation to Finland, but equally apply to the Netherlands: Miia HalmeTuomisaari Human Rights in Action (Helsinki University Printing House, Helsinki, 2008) at 4 and 9.

164 Hon Sir Anthony Mason "Human Rights: Interpretation, Declarations of Inconsistency and the Limits of Judicial Power" (2011) 9 NZJPIL 1 at 5.

165 Finland only acceded to the ECHR in 1990, though it had been a party to several HRTs since the early 1970s. Until Finland's ratification of ECHR, human rights awareness was limited and lower than the other Nordic countries that were already a party to the ECHR: Allan Rosas "Finland" in Robert Blackburn and Jörg Polakiewicz (eds) Fundamental Rights in Europe: The European Convention on Human Rights and its Member States, 1950-2000 (Oxford University Press, Oxford, 2002) 289 at 311; Juha Lavapuro, Tuomas Ojanen and Martin Scheinin "Rights-Based Constitutionalism in Finland and the Development of Pluralist Constitutional Review" (2011) 9 ICON 505 at 506.

166 The High Commissioner for Human Rights observed in 2006 that:

... governments frequently pay insufficient attention to the recommendations adopted by the treaty bodies, and lack of awareness or knowledge among national constituencies about the monitoring procedures and their recommendations, renders these invisible at the national level.

- Concept Paper on the High Commissioner's Proposal for a Unified Standing Treaty Body: Report by the Secretariat HRI/MC/2006/2 (2006) at [26]. Another study about the impact of UN HRTs in 20 different 
If one finds it desirable - as the present author does - to further entrench a true human rights culture in New Zealand, the most obvious way would be to strengthen internal checks. One option would be to create a Parliamentary Committee on Human Rights as exists in the United Kingdom. Another more far-reaching measure would be the amendment of s 4 of the NZBORA. The situation in Finland might be instructive for New Zealand. Until the end of the 1990s, constitutional judicial review was prohibited, because of a similar belief in the idea of majoritarian democracy and parliamentary supremacy. Constitutional amendments in 2000, however, empowered courts to not apply a statutory provision when the provision "would be in evident conflict with the Constitution". ${ }^{167}$ Fears of judicial activism turned out to be unwarranted, because Finnish courts have made only sparse use of the new amendments and have hardly changed their initial position of self-restraint vis-à-vis the legislature. What is, however, interesting is that parliamentary scrutiny of Bills seems to have become more thorough as a result. ${ }^{168}$ Changing s 4 so that courts can declare legislative enactments invalid which are manifestly inconsistent with the NZBORA (as a last resort), would require Parliament to consider NZBORA and international human rights more extensively and build up expertise around them. ${ }^{169}$ If Parliament is doing its job properly than eventually there will be no need for courts to make use of such a power. Whether this also leads to a true human rights culture remains to be seen, but it is at least worth trying.

\section{CONCLUSION}

As this article has shown, the impact of the reporting process is far from perfect. Nonetheless, the process of reporting is now more on the political agenda than it was 10 years ago. That is to say, the organisation of the process of reporting has improved since the MOJ took over the responsibility for the compilation of reports. In addition, both the NZHRC and NGOs are more involved by way of compiling shadow reports and attending the TB sessions.

Nonetheless, there is still no formal follow-up mechanism to respond to $\mathrm{COs}$ at the governmental level, except for the UNCROC COs 1997 and 2003. Neither is there clear leadership or one department with the principal responsibility for the implementation of HRTs and the reporting process. ${ }^{170}$ Crucial for the impact of international human rights law in New Zealand is the

countries reached a rather similar conclusion: Christof Heyns and Frans Viljoen "The impact of the United Nations Human Rights Treaties on the Domestic Level" (2001) 23 Hum Rts Q 483.

167 The Constitution of Finland, s 106.

168 Courts have used s 106 only four times since 2000: Lavapuro, Ojanen and Scheinin, above n 165, at 524; Rosas in Blackburn and Polakiewicz, above n 165, at 297.

169 Even Jeremy Waldron, who staunchly opposes strong judicial review, stated in relation to New Zealand that "legislative procedures have become so impoverished that another layer of review is necessary": Jeremy Waldron "Compared to What? Judicial Activism and New Zealand's Parliament" [2005] NZLJ 441 at 442.

170 See the reference to the suggestion of Chief Commissioner Noonan of the NZHRC and the general discussion during the New Zealand Diversity Forum 09: Greatrex, above n 15, at 96, 113-114 and 175-176. 
domestic lobbying of strong NGOs. ${ }^{171}$ This is still rather minimal, except for in regard to UNCROC. One major actor that is also somewhat absent is Parliament. This is a pity, especially in a country like New Zealand where "the primary body which protects human rights in this country is in fact the New Zealand Parliament", ${ }^{172}$ and human rights compliance is not accomplished by court order. ${ }^{173}$ Change on the basis of COs, thus, needs to occur primarily through political processes instead of litigation. ${ }^{174}$

This article has shown that several COs, especially those of the UNCROC Committee, and, to a lesser extent, the CAT Committee, have been partly effective or have influenced a change in policy or legislation. This means that the major obstacles for compliance with COs, which are the deficient functioning and credibility of the TBs as well as several domestic factors related to the political culture of New Zealand, can be overcome. However, this requires government officials and ministers to make a concerted effort to address COs by way of an action plan, such as the UNCROC Work Programme. Alternatively, MPs can also take the initiative to submit a Bill to meet the concerns of the TBs in COs, such as for the repeal of s 59 of the Crimes Act 1961 and the withdrawal of the reservation of women in armed forces. Often, pressure and lobbying from domestic actors like NGOs, the NZHRC, lawyers and academics, is needed to make sure that the Government does not simply discard COs or that MPs are aware of and make use of COs.

171 Margaret Bedggood gave the "long saga" of the Zaoui court case, ACYA, and the Child Poverty Action Group as examples of impact: Margaret Bedggood "The International Law Dimension of Human Rights in New Zealand" in Sylvia Bell (ed) Brookers Human Rights Law (Brookers, Wellington, 2010) at [1.02].

172 Hon Dr Michael Cullen MP "Human rights and the Foreshore and Seabed" (Human Rights Commission Speakers Forum, National Archives Building, Wellington, 1 June 2004).

173 Petra Butler "15 Years of the NZ Bill of Rights: Time to Celebrate, Time to Reflect, Time to Work Harder?" [2006] Victoria University Human Rights Research 1. Others also pointed to the parliamentary nature of Bill of Rights protections and their realisation through "political rights review". Janet Hiebert characterised the NZBORA as a "Parliamentary Bill of Rights": Hiebert as cited in Geddis "Which Is To Be The Master? Rights-friendly Statutory Interpretation in New Zealand and the United Kingdom", above n 71, at 735; Kelly, above n 53, at 304 and 308. The parliamentary nature is the result of s 4 NZBORA, which prevents courts from declaring legislative enactments inconsistent with NZBORA invalid. Claudia Geiringer pointed out that questions of legislative incompatibility with NZBORA or human rights often go beyond a pure legal analysis. Courts are often unwilling to undertake such an examination because they are "not comfortable with being placed in the role of critic of the legislative branch": Claudia Geiringer "On a Road to Nowhere: Implied Declaration of Inconsistency and the New Zealand Bill of Rights Act" (2009) 40 VUWLR 613 at 646; Geiringer "The Principle of Legality and the Bill of Rights Act: A Critical Examination of $R v$ Hansen", above n 60, at 70-71; Geddis "The Comparative Irrelevance of the NZBORA to Legislative Practice", above n 54, at 481.

174 David Erdos "Judicial Culture and the Politicolegal Opportunity Structure: Explaining Bill of Rights Legal Impact in New Zealand" (2009) 34 Law and Social Inquiry 95 at 117. 
